\title{
Pyrometallurgical Treatment of Apatite Concentrate with the Objective of Rare Earth Element Extraction: Part I
}

\author{
Tianming Sun ${ }^{1} \cdot$ Mark William Kennedy ${ }^{2}$ Lourdes Yurramendi ${ }^{3}$.

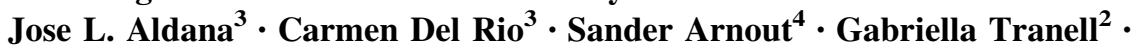 \\ Ragnhild E. Aune ${ }^{2}$
}

Published online: 30 November 2017

(C) The Author(s) 2017. This article is an open access publication

\begin{abstract}
Apatite, $\mathrm{Ca}_{5}\left(\mathrm{PO}_{4}\right)_{3} \mathrm{~F}$, concentrate from LKAB in Kiruna, Sweden, has been characterized and pyrometallurgically treated using (i) silicon metal and fluxes to extract phosphorus and transition metals at $1600{ }^{\circ} \mathrm{C}$ (Part I publication), and (ii) carbon to extract phosphorus without fluxing at temperatures exceeding $1800{ }^{\circ} \mathrm{C}$ (Part II publication), with the ultimate objective to recover rare earth elements from the resulting slag/residue phases. A variety of methods (SEM/EDS, EPMA, DTA-TGA, Sessile drop, ICP-MS/OES, and XRD) have been used for the characterization and analysis of both the concentrate and reaction products. Elemental deportment, except for the rare earth metals, is broadly in line with the equilibrium thermodynamic predictions performed using HSC Chemistry ${ }^{\circledR}$. Phase diagrams were predicted using FactSage ${ }^{\circledR}$ and a custom phosphate database to explain the observed melting/fluxing behaviors.
\end{abstract}

Keywords Apatite $\cdot$ Rare earth $\cdot$ REE $\cdot$ Silicon · Phosphorus $\cdot$ Smelting

The contributing editor for this article was Bernd Friedrich.

Mark William Kennedy

mark.w.kennedy@ntnu.no

1 School of Chemical Science and Engineering, Royal Institute of Technology (KTH), 10044 Stockholm, Sweden

2 Department of Materials Science and Engineering, Norwegian University of Science and Technology (NTNU), 7491 Trondheim, Norway

3 TECNALIA Parque Tecnológico de San Sebastián, Mikeletegi Pasealekua, 2 E-20009 Donostia-San Sebastián, Gipuzkoa, Spain

4 InsPyro, Kapeldreef 60, 3001 Leuven, Belgium

\section{Introduction}

Rare earth elements (REEs) are considered by the European Union (EU) to be of strategic significance to the European economy. They are also deemed to possess both important economic value, due to their many applications, and to have the most significant supply risk of all classes of materials evaluated by the "Working Group on Defining Critical Raw Materials" [1]. Areas of importance comprising REEs are $38 \%$ metallurgical (magnets $20 \%$, batteries $8 \%$, other metallurgy $10 \%$ ), $20 \%$ catalysts (fluid catalytic cracking $13 \%$, autocatalysts $6 \%$, other catalysts $1 \%$ ), and $42 \%$ other (polishing $15 \%$, glass $7 \%$, phosphors $7 \%$, ceramics $5 \%$, and not defined 8\%) [2]. A detailed breakdown of the REE consumption by metal and application can be found in documents prepared by the U.S. Geological Survey (USGS), such as by Goonan 2011 [3]. The relative abundances of the different REEs within the earth's crust and the mineralogy of the rare earth minerals have been discussed in detail by Castor and Hedrick [4].

The supply risk for Europe associated with REEs became readily apparent when China in 2010 changed its export quotas, which in turn resulted in a clear spike in market prices as indicated in Fig. 1 [5]. This was not only due to the nonnative REE source in Europe, but also a result of the extremely low recycling rates, which in 2011 was reported to be $<1 \%$ from end-of-life products [3]. In order to reduce the chances of a similar supply risk reappearing in Europe in the future, as well as to increase the competence in REE metallurgy, the European Commission (EC) financed a number of projects/initiatives focusing on recovery of REEs from waste material, i.e., ERECON [6], Hydro-WEEE [7], EURARE [8], RECLAIM [9], REEcover [10], etc. The REEcover project addresses REE recycling from end-of-life WEEE, as well as increased supply by studying REE recovery from an industrially 
Fig. 1 Historic rare earth oxide production and prices (in constant 1998 dollars) [5] (Color figure online)

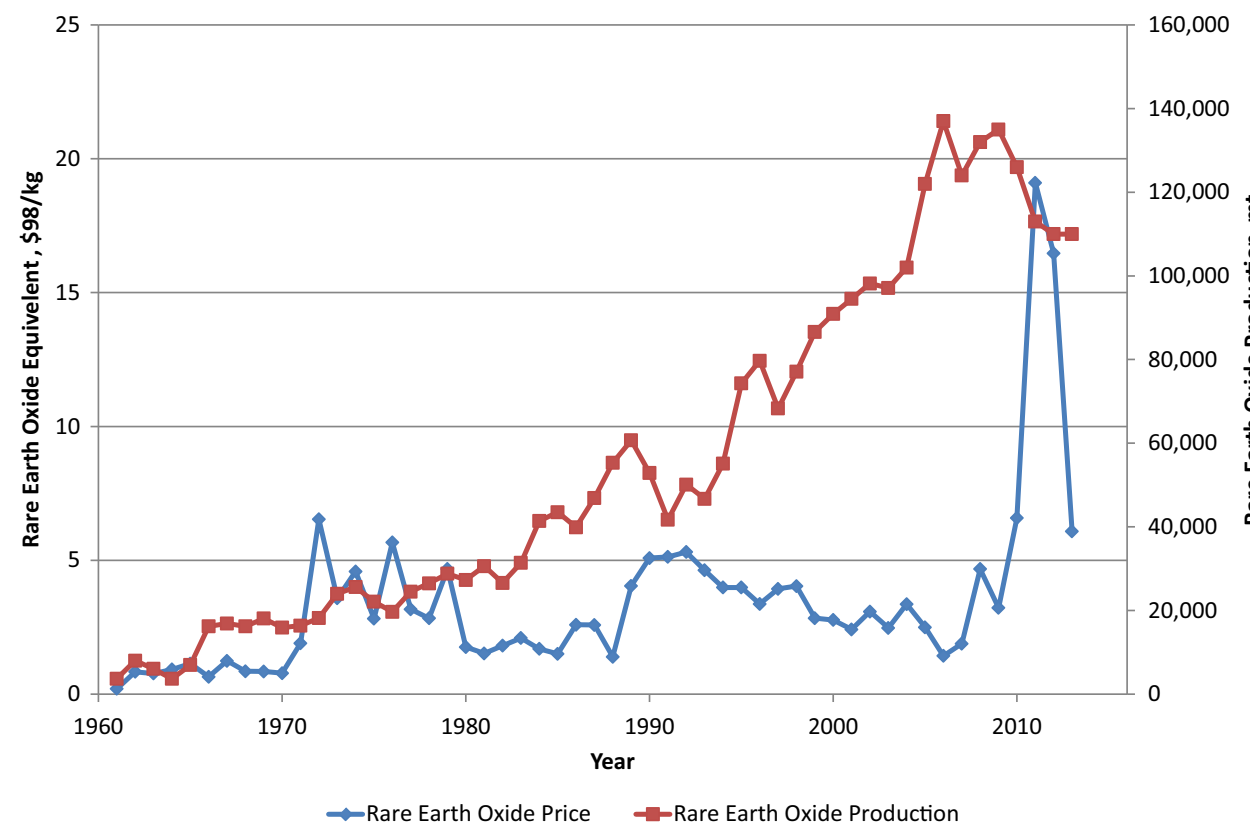

stockpile of $40 \mathrm{M}$ tonnes of tailings, and an annual production of an additional $2 \mathrm{M}$ tonnes, the site is a significant 'primary' REE resource in Europe, with a possible annual production of $\sim 4000$ tonnes REE/year.

In order to evaluate the viability of extraction of REEs from the apatite concentrate, the following high-temperature analyses and pyrometallurgical experiments, as reported in two interconnected papers (Parts I and II; to be communicated), have been performed, see Fig. 2, i.e.:

(1) Initial characterization of the apatite concentrate to determine its composition and mineralogy before and after heat treatment (Part I).

(2) DTA-TGA analysis of the behavior of the apatite concentrate during heating (Part I).

(3) Metal-extraction experiments in order to concentrate REEs for downstream hydrometallurgical treatment:

(a) Using silicon to remove phosphorus and reducible metal species with and without fluxing (Part I).

(b) Using carbon to remove predominantly phosphorus, and to produce a rare earth oxide (REO) that could potentially be further processed to recover REE (Part II by Kennedy et al. [12]).

\section{Apatite Concentrate Characterization and Behavior During Heating}

\section{Chemical and Mineralogical Characterization}

The apatite concentrate used in the present study, is an upgraded form of the original apatite tailings, consisting of 
a mixture of mainly fluorapatite $\left(\mathrm{Ca}_{5}\left(\mathrm{PO}_{4}\right)_{3} \mathrm{~F}\right)$ with carbonates (Calcite/Dolomite), and residual iron containing minerals. In Table 1, the chemical analysis of the apatite concentrate has been expressed as simple oxides, to which loss on ignition (LOI), F- and total REO have been added. The major mineralogical species reflected by the assays in Table 1 are approximately: $77.4 \%$ Fluorapatite $\left(\mathrm{Ca}_{5}\right.$ $\left.\left(\mathrm{PO}_{4}\right)_{3} \mathrm{~F}\right), \quad 9.1 \%$ Calcite $\left(\mathrm{CaCO}_{3}\right), \quad 5.9 \%$ Dolomite $\left(\mathrm{CaMg}\left(\mathrm{CO}_{3}\right)_{2}\right)$, and $1.4 \%$ Quartz $\left(\mathrm{SiO}_{2}\right)$. To achieve a unique solution, all magnesium was assumed as dolomite, calcite was estimated from LOI minus the dolomite contribution, fluorapatite was calculated from total calcium minus the dolomite and calcite contributions, and all silica was assumed to be quartz. Calculated results are in good agreement with the reported mineralogy by the LKAB lab in Kiruna, Sweden: $83.1 \%$ Apatite, $10.1 \%$ Calcite, $4.6 \%$ Dolomite, $1.6 \%$ Clinochlore $\left((\mathrm{Mg}, \mathrm{Fe}, \mathrm{Al})_{6}\left[(\mathrm{Al}, \mathrm{Si})_{4} \mathrm{O}_{10}\right]\right.$ $\left.(\mathrm{OH})_{8}\right)$, and $0.6 \%$ Quartz [13].

The rare earth containing species have been found to be monazite, allanite, and apatite, as indicated in Figs. 3 and 4 $[11,17]$. More recently, titanite and several other minor species containing REE have also been identified [18]. A number of independent laboratories have analyzed the apatite using five different analytic methodologies in roundrobin testing. It has proven remarkably difficult to analyze these mineral samples containing both silicates and low concentrations of REOs [19]. Alkaline fusion in lithium metaborate, followed by dissolution in dilute nitric acid, was particularly successful when combined with either ICP-OES or MS. A summary of the available lab results for apatite indicating the average, number of samples analyzed, and coefficient of variance of the results, is indicated in Table 2.

An SEM image of the concentrate is shown in Fig. 5, and the mineralogical descriptions of the different points are described in Table 3 based on EDS microprobe analyses.

The total percentages of $\mathrm{La}, \mathrm{Ce}, \mathrm{Nd}$, and $\mathrm{Y}$ are much higher (of the order of tens of percent) in the monazite and

Table 1 The chemical analysis of the apatite concentrate expressed as simple oxides based on mineralogical analysis [14], average roundrobin chemical results (3 laboratories) [15], and measured LOI

\begin{tabular}{lcll}
\hline Component & wt $\%$ & Component & wt\% \\
\hline $\mathrm{CaO}$ & 50.0 & $\mathrm{MnO}$ & 0.19 \\
$\mathrm{P}_{2} \mathrm{O}_{5}$ & 32.7 & $\mathrm{~K}_{2} \mathrm{O}$ & 0.053 \\
$\mathrm{Fe}_{2} \mathrm{O}_{3}$ & 1.57 & $\mathrm{TiO}_{2}$ & 0.034 \\
$\mathrm{SiO}_{2}$ & 1.43 & $\mathrm{~F}-$ & 2.91 \\
$\mathrm{MgO}$ & 1.29 & LOI $\left(1450^{\circ} \mathrm{C}\right)$ & 6.8 \\
$\mathrm{Na}_{2} \mathrm{O}$ & 0.36 & & ppm \\
$\mathrm{Al}_{2} \mathrm{O}_{3}$ & 0.25 & Total REO & 6476 \\
\hline
\end{tabular}

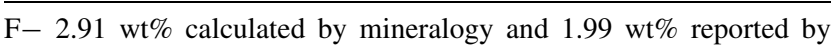
semiquantiative XRF [16] allanite phases than those in the general apatite phase, raising hopes that it may be possible to melt, cool, precipitate, and grow large separable phosphate- or silicatebased crystals containing high concentrations of REEs for subsequent physical separation and extractive metallurgy. The possibility to grow such crystals was the subject of the slag saturation and slow cooling experiments. The initial results of these have been reported elsewhere [20].

The phases initially present in the apatite concentrate have been verified by XRD as shown in Fig. 6, and found to include in quantities significant enough to be observed: apatite, calcite, dolomite, talc, allanite, and monazite.

\section{High-Temperature Behavior of Apatite Concentrate Under Argon}

The concentrate being predominantly apatite was expected to have a melting point close to that reported for synthetic apatites, i.e., of the order of $1608-1622{ }^{\circ} \mathrm{C}$ [21]. Initially, phase diagram information for the 'phosphate' containing system was lacking, and screening experiments were therefore conducted at the Norwegian University of Science and Technology (NTNU) in Trondheim, Norway, in an electrically heated sessile drop apparatus using a number of substrates in order to observe the melting, as well as the interactions with the substrates. Optical observation of apatite concentrate on various substrates (graphite, molybdenum, and tantalum) in an electrically heated wetting furnace indicated a liquidus point of $\sim 1598 \pm 5{ }^{\circ} \mathrm{C}$ [20].

DTA-TGA tests were then conducted in a flowing argon stream $(12 \mathrm{NL} / \mathrm{h})$ using a molybdenum crucible, which the previous wetting experiments had shown to be a compatible material (graphite, while suitable, reacts to produce $\mathrm{P}_{2}$ gas, and tantalum was more expensive and less readily available than molybdenum). The DTA-TGA results showed that there was a mass loss of $\sim 6.8 \%$ in flowing argon in the range of $650-910{ }^{\circ} \mathrm{C}$, as indicated on Fig. 7. The loss of $\mathrm{CO}_{2}$ was verified by mass spectrometer readings, as shown on Fig. 8 . During three separate calcining experiments run with $50-100 \mathrm{~g}$, a mass loss of $6.62 \mathrm{wt} \%$, with a standard deviation of $0.027 \%$, was observed in air at $1000{ }^{\circ} \mathrm{C}$. Similarly, a mass loss of $6.8 \%$ was found for $20 \mathrm{~g}$ calcined at $1450{ }^{\circ} \mathrm{C}$. Thermodynamic analysis using HSC Chemistry ${ }^{\circledR}$ version 7.1 [22] reveals that the dolomite should decompose into the double oxide at $606{ }^{\circ} \mathrm{C}$, and that calcite should decompose at $887^{\circ} \mathrm{C}$. Apparent values will vary due to the dilution from argon, the diffusion time out of the sample crucible, and the plug flow in the flowing argon stream within the DTA-TGA apparatus.

Using the DTA-TGA, an endothermic reaction (melting) was observed in the temperature range of $1112-1613{ }^{\circ} \mathrm{C}$, as shown in Figs. 7 and 8. For comparison, the published melting point for the most-prevalent apatite in the concentrate (fluorapatite) is $1616^{\circ} \mathrm{C}$ [21]. 
Fig. 3 EPMA results indicating mainly the presence of $\mathrm{Ca}_{5}\left(\mathrm{PO}_{4}\right)_{3} \mathrm{~F}$ (fluorapatite), $\mathrm{CaCO}_{3}$ (calcite), and $(\mathrm{Ce}, \mathrm{Nd}) \mathrm{Al}_{2}\left(\mathrm{SiO}_{4}\right)\left(\mathrm{Si}_{2} \mathrm{O}_{7}\right) \mathrm{O}(\mathrm{OH})$ (allanite) [20] (Color figure online)

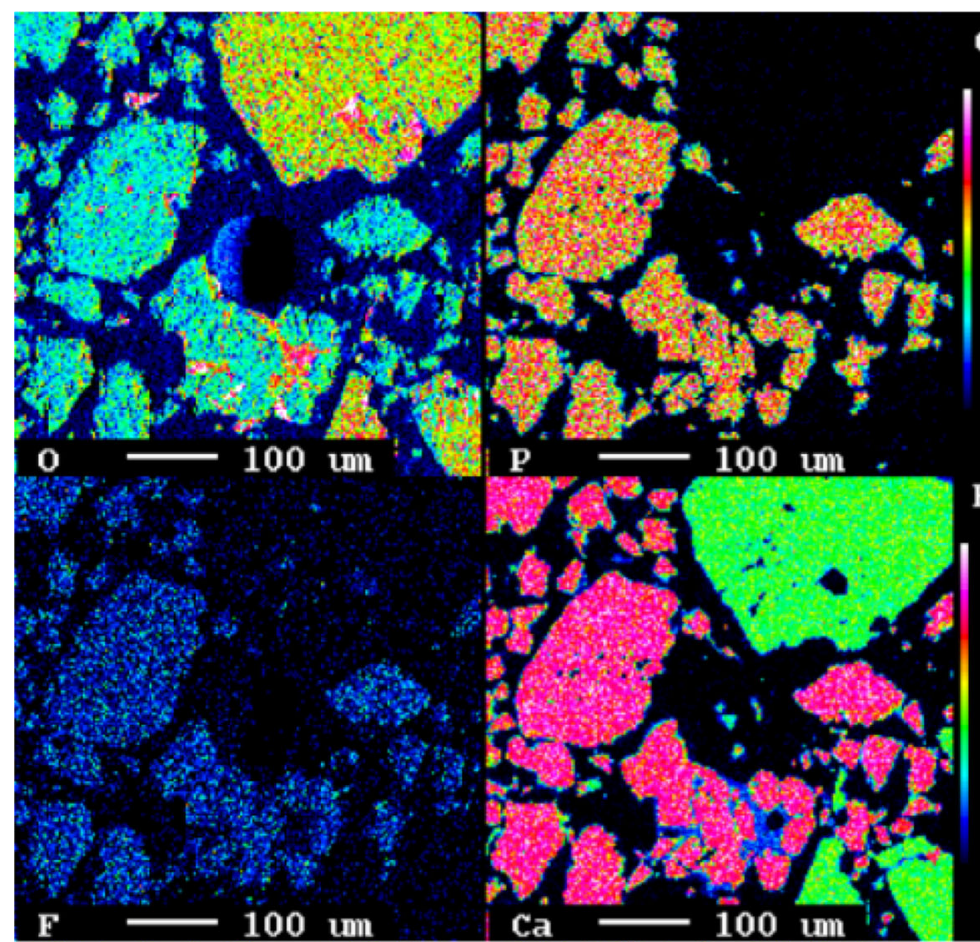

o Cn P Cn $60.00,20.00$ $52.50 \quad 17.50$ $45.00 \quad 15.00$ $37.50 \quad 12.50$ $30.00 \quad 10.00$ $22.50 \quad 7.50$ $15.00 \quad 5.00$ $7.50 \quad 2.50$ $0.00 \quad 0.00$ 15.123 .98 F Cn Ca Cn $7.000,40.00$ 6.12535 .00 5. $250 \quad 30.00$ 4.37525 .00 3.50020 .00 2.62515 .00

$\begin{array}{ll}1.750 & 10.00\end{array}$

$0.875 \quad 5.00$

$0.000 \quad 0.00$

$0.000 \quad 14.61$

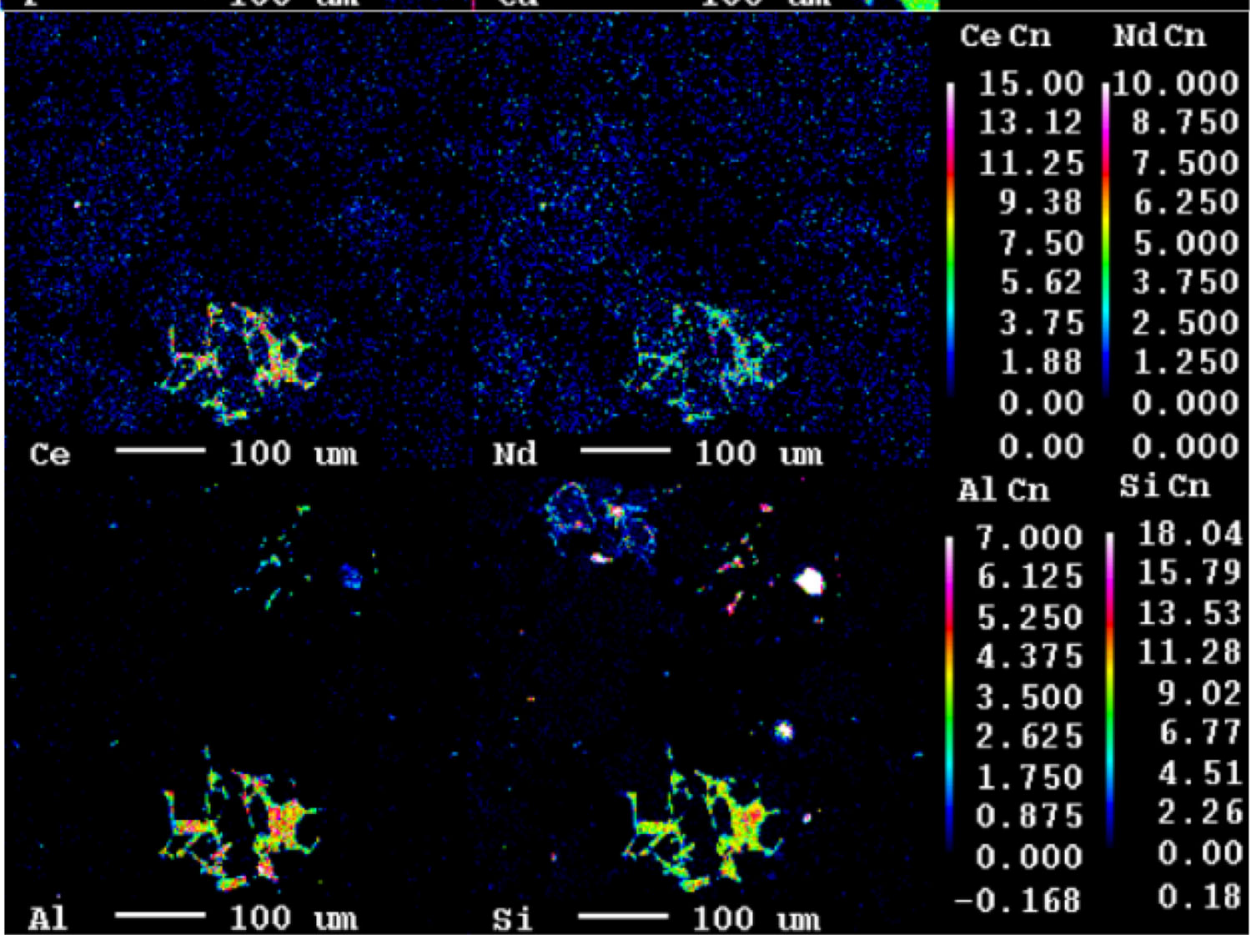

Phosphorus Extraction Experiments Using Silicon

\section{Background for Extraction Experiments Using Silicon}

The experimental work was challenging due to the limited information initially available on the behavior and properties of this high phosphorus-containing apatite concentrate. Finding compatible materials and the lack of fundamental thermodynamic information, e.g., phase diagrams and REE behavior in related slag systems, further complicated the work.

Data on rare earth oxides stability were, however, readily available as shown in Fig. 9. The data in Fig. 9 show that all of the REOs are more stable than silica, and that silicon lies below phosphorus and all of the transition 
Fig. 4 EPMA results indicating the presence of the $(\mathrm{Y}, \mathrm{La}, \mathrm{Ce}, \mathrm{Nd}) \mathrm{PO}_{4}$ monazite phase (large bright particle in red circle and nearby small white dots) [20] (Color figure online)

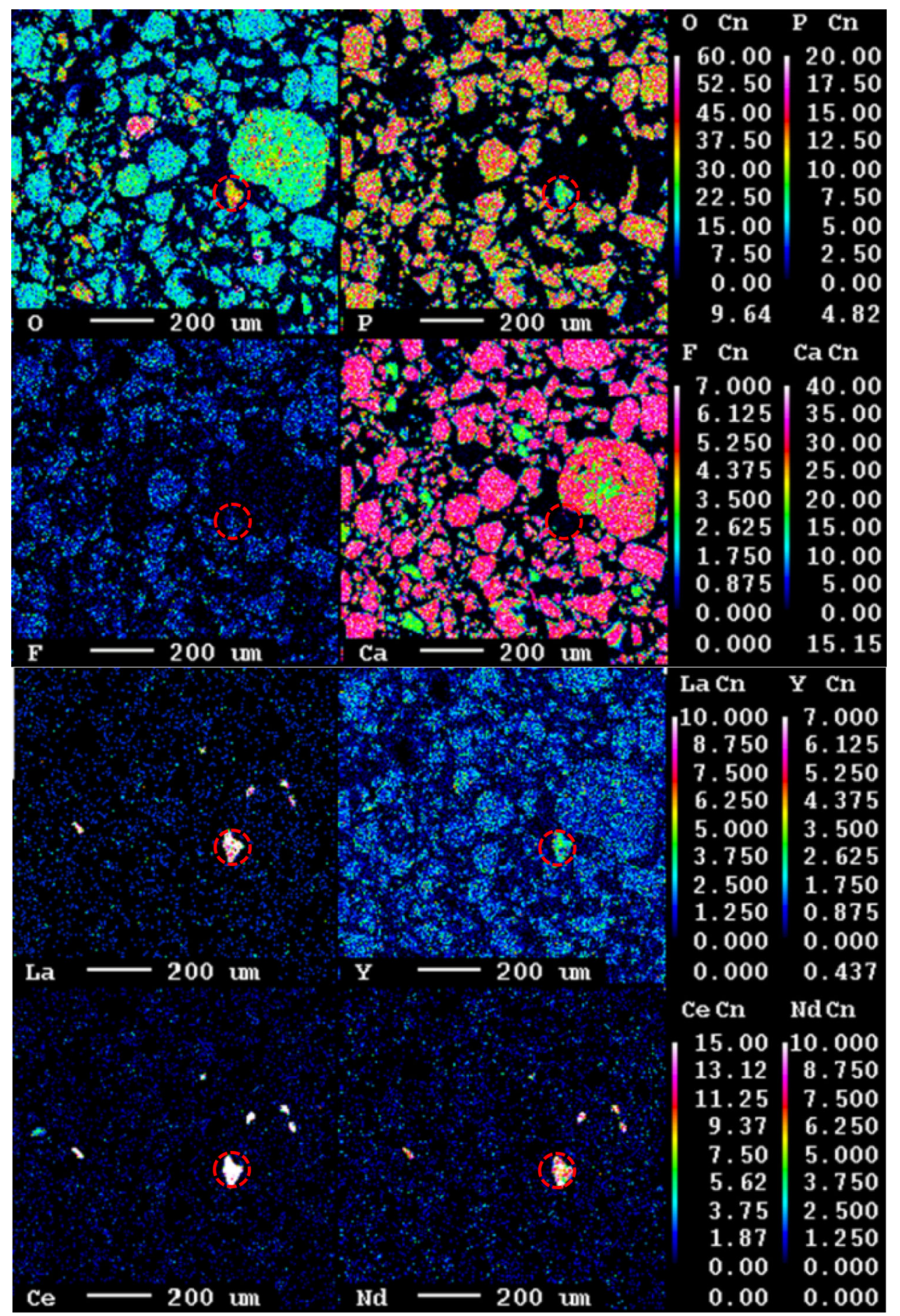

elements, as indicated by the most stable transition metal oxides $\mathrm{Cr}_{2} \mathrm{O}_{3}$ and $\mathrm{MnO}$. Silicon metal is therefore (in theory) an ideal metal to extract phosphorus and different transition metals (as well as alkali metals) without the removal of any rare earth metals. From the relative positions shown in Fig. 11, one would expect that the REEs would distribute nearly quantitatively to the slag phase. The use of silicon as a reductant adds silica to any resulting slag, and the complete reduction of phosphorus will predominantly leave a calcium silicate slag.

Examination of Table 1 shows that complete reduction of silicon metal reducible species including phosphorus, would yield a 'binary' slag containing about $43 \mathrm{~mol} \% \mathrm{SiO}_{2}$ having a liquidus of $\sim 1464{ }^{\circ} \mathrm{C}$ (composition calculated by excluding all $\mathrm{Ca}$ present as $\mathrm{CaF}_{2}$ ), as indicted in Fig. 10. A liquidus of $\sim 1379^{\circ} \mathrm{C}$ was found for the multicomponent 
Table 2 Assay of the apatite concentrate produced from LKAB tailing (Kiruna, Sweden). Samples with fewer than five analyses (except for $\mathrm{Si}$ ) are from initial pre-roundrobin results

\begin{tabular}{|c|c|c|c|c|}
\hline Element & Units & Average & \# Samples & C.V. \% \\
\hline $\mathrm{Ca}$ & $\%$ & 35.7 & 7 & 4.7 \\
\hline $\mathrm{P}$ & $\%$ & 14.1 & 7 & 4.6 \\
\hline $\mathrm{Fe}$ & $\%$ & 1.09 & 7 & 12.5 \\
\hline B & $\%$ & 0.97 & 1 & N.A. \\
\hline $\mathrm{Mg}$ & $\%$ & 0.78 & 7 & 9.3 \\
\hline $\mathrm{Si}$ & $\%$ & 0.67 & 3 & 22.9 \\
\hline $\mathrm{Na}$ & $\mathrm{mg} / \mathrm{kg}$ & 2636 & 3 & 66.4 \\
\hline $\mathrm{Mn}$ & $\mathrm{mg} / \mathrm{kg}$ & 1504 & 3 & 9.0 \\
\hline $\mathrm{Al}$ & $\mathrm{mg} / \mathrm{kg}$ & 1313 & 3 & 34.2 \\
\hline $\mathrm{Ti}$ & $\mathrm{mg} / \mathrm{kg}$ & 560 & 3 & 11.1 \\
\hline $\mathrm{K}$ & $\mathrm{mg} / \mathrm{kg}$ & 443 & 3 & 75.9 \\
\hline $\mathrm{Cu}$ & $\mathrm{mg} / \mathrm{kg}$ & 135 & 3 & 40.6 \\
\hline $\mathrm{Ni}$ & $\mathrm{mg} / \mathrm{kg}$ & 11.7 & 2 & 15.7 \\
\hline $\mathrm{Ce}$ & $\mathrm{mg} / \mathrm{kg}$ & 1865 & 7 & 3.6 \\
\hline Dy & $\mathrm{mg} / \mathrm{kg}$ & 82 & 7 & 16.7 \\
\hline $\mathrm{Er}$ & $\mathrm{mg} / \mathrm{kg}$ & 50 & 3 & 1.7 \\
\hline $\mathrm{Eu}$ & $\mathrm{mg} / \mathrm{kg}$ & 17 & 7 & 15.1 \\
\hline $\mathrm{Gd}$ & $\mathrm{mg} / \mathrm{kg}$ & 131 & 7 & 4.9 \\
\hline Ho & $\mathrm{mg} / \mathrm{kg}$ & 18 & 3 & 7.4 \\
\hline $\mathrm{La}$ & $\mathrm{mg} / \mathrm{kg}$ & 840 & 7 & 4.9 \\
\hline $\mathrm{Lu}$ & $\mathrm{mg} / \mathrm{kg}$ & 5.9 & 7 & 20.0 \\
\hline $\mathrm{Nd}$ & $\mathrm{mg} / \mathrm{kg}$ & 808 & 7 & 5.0 \\
\hline $\operatorname{Pr}$ & $\mathrm{mg} / \mathrm{kg}$ & 187 & 6 & 13.4 \\
\hline $\mathrm{Sm}$ & $\mathrm{mg} / \mathrm{kg}$ & 135 & 7 & 11.0 \\
\hline $\mathrm{Tb}$ & $\mathrm{mg} / \mathrm{kg}$ & 16 & 5 & 23.3 \\
\hline $\mathrm{Tm}$ & $\mathrm{mg} / \mathrm{kg}$ & 5.7 & 3 & 20.7 \\
\hline Y & $\mathrm{mg} / \mathrm{kg}$ & 590 & 7 & 4.5 \\
\hline $\mathrm{Yb}$ & $\mathrm{mg} / \mathrm{kg}$ & 33 & 1 & N.A. \\
\hline
\end{tabular}

slag using FactSage ${ }^{\circledR}$ calculations to account for the impact of $\mathrm{CaF}_{2}$ and other minor slag components. This would in theory yield a technically feasible process at temperatures easily achievable in the lab; however, the indicated values are only applicable after full removal of phosphorus.

Fluxing to reduce the product slag liquidus is one option to achieve a rapid and efficient phosphorus removal process. Obvious candidates include $\mathrm{SiO}_{2}$ and $\mathrm{Al}_{2} \mathrm{O}_{3}$. The $\mathrm{CaO}-\mathrm{Al}_{2} \mathrm{O}_{3}-\mathrm{SiO}_{2}$ phase diagram, calculated using FactSage ${ }^{\circledR}$, is shown in Fig. 11. The diagram represents the endpoint of the system after complete phosphorus removal, as well as ignoring the small contribution of fluoride present. Three possible low melting point targets are indicated on Fig. 11, which can be achieved using: (i) silica flux, (ii) clay flux (composition showed in Table 4), and (iii) alumina flux. These three approaches were each considered in the extraction experiments conducted by TECNALIA in

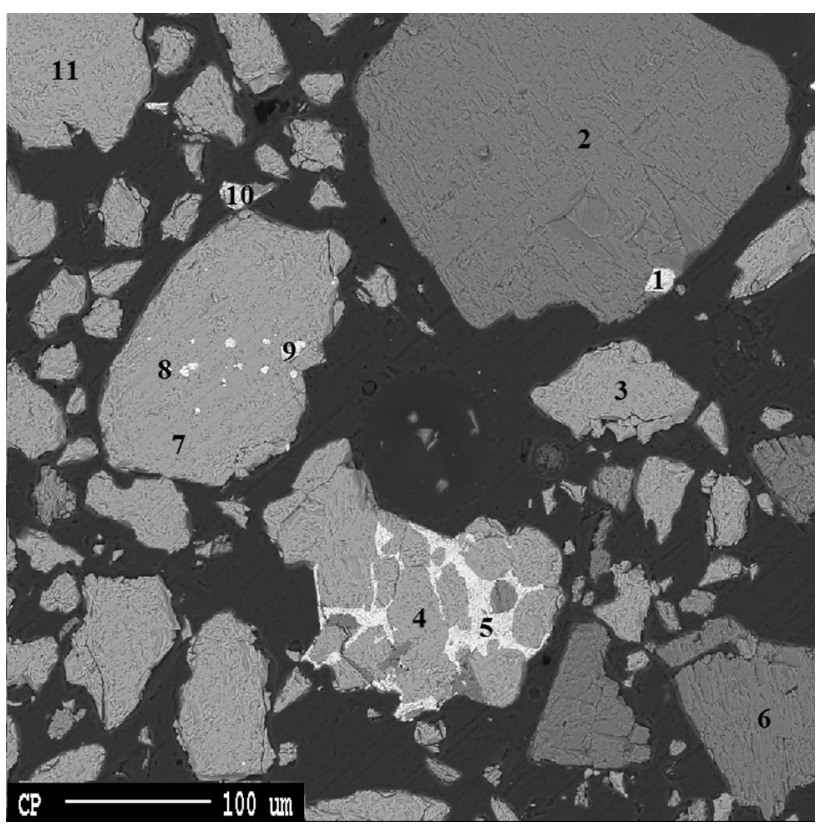

Fig. 5 Electron backscattered image of apatite concentrate indicating the points measured, and the phases identified as presented in Table 3 [20] (Color figure online)

Table 3 Phases indicated in Fig. 5 using EDS [20]

\begin{tabular}{lllll}
\hline & Fluorapatite & Allanite & Calcite & Iron-oxide \\
\hline 1 & & & & X \\
2 & & & X & \\
3 & X & & & \\
4 & X & & & \\
5 & & $X$ & & \\
6 & & & & \\
7 & X & & & \\
8 & X & & & X \\
9 & & & X \\
10 & & & \\
11 & X & & & \\
\hline
\end{tabular}

San Sebastián, Spain (one of the REEcover consortium partners), as indicated on Fig. 11.

As previously mentioned, the phase diagram in Fig. 11 is only applicable after the phosphorus has been removed, and it does not provide information regarding possible difficulties that might be encountered during the process of phosphorus removal from a $\mathrm{CaO}-\mathrm{P}_{2} \mathrm{O}_{5}-\mathrm{SiO}_{2}-\mathrm{Al}_{2} \mathrm{O}_{3}$ system. The required $\mathrm{P}_{2} \mathrm{O}_{5}$ containing phase diagrams were not available at the time of the experimental work; however, the required phosphorus slag database was developed by the EU sponsored project RecoPhos [25]. The necessary phase diagrams have now been generated by InsPyro (a REcoPhos consortium partner), on behalf of the REEcover 
Fig. 6 XRD results from using a powder diffractometer (Bruker D8 Advance A25) operating in Bragg Bretano mode, and utilizing $\mathrm{Cu} \mathrm{K}$-alpha radiation. A $2 \theta$ range of $10^{\circ}-75^{\circ}$ using a voltage of $30 \mathrm{kV}$. Collected data were analyzed using the software DIFFRAC.EVA V3.0 from Bruker with the database, PDF-4+2013 RDB (Color figure online)
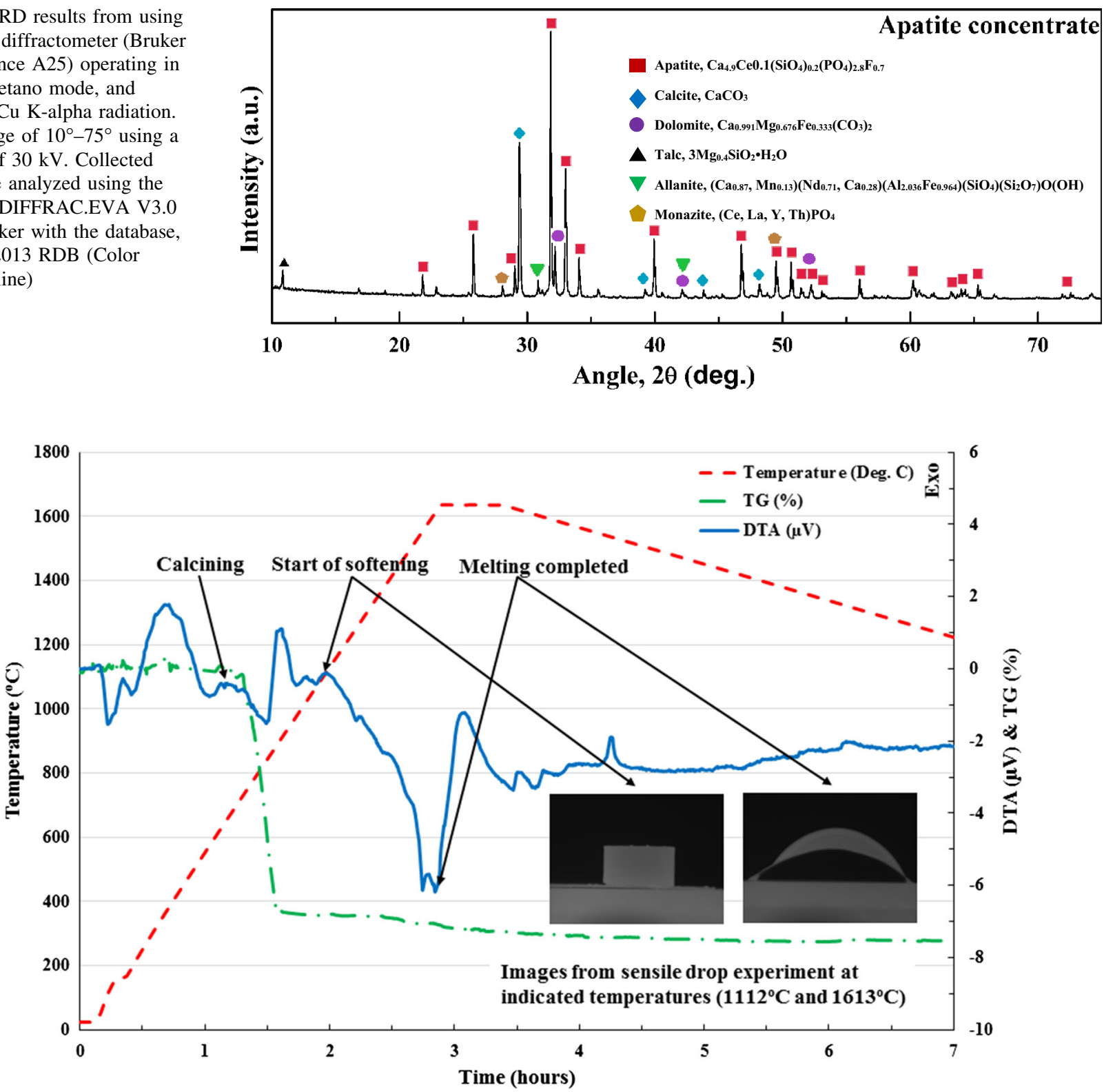

Fig. 7 DTA-TGA results of the apatite concentrate using a molybdenum crucible under argon atmosphere. The temperature curve (red dotted line), the thermal gravimetric curve (green dot-dash line), and

project, and the implications of these diagrams will be addressed in the present work.

Some of the applicable thermodynamics for the silicothermic reduction of fluorapatite concentrate are explored in Table 5 and Fig. 12 using calculations performed with HSC Chemistry ${ }^{\circledR}$ version $7.1[22]$ and assuming ideal solutions. From the reactions listed in Table 5 and the phosphorus distribution shown on Fig. 12, it was expected that substantial quantities of $\mathrm{P}, \mathrm{K}$ and $\mathrm{Na}$ would be distributed to the gas phase in equilibrium with pure silicon at $1600{ }^{\circ} \mathrm{C}$ (see reactions (3), (13) and (14)). This is in good agreement with the experiences obtained during industrial pyrometallurgical phosphorus production. the differential thermal analysis curve versus time (solid blue line) are presented (Color figure online)

\section{Apparatus and Procedures}

A resistance heated 'muffle' furnace rated up to $1700{ }^{\circ} \mathrm{C}$ was used for the silicon extraction experiments. This furnace had dimensions of $10^{\prime \prime} \times 10^{\prime \prime} \times 10^{\prime \prime}(\mathrm{L} \times \mathrm{W} \times \mathrm{H})$ and used eight $\mathrm{MoSi}_{2}$ heating elements. To control the operating temperature, a type-S thermocouple was inserted through the end wall of the furnace. Argon was injected, through a ceramic tube introduced through a hole made at the bottom of the furnace, in order to create a low oxygen atmosphere. Another ceramic probe was installed through the furnace roof so that some of the atmosphere could be 
extracted and analyzed/logged for oxygen concentration. A high flowrate of argon, $60 \mathrm{NL} / \mathrm{h}$, was required to keep the muffle furnace at $<2.5 \% \mathrm{O}_{2}$, and under these conditions, the furnace could only achieve a stable operating temperature of $1600{ }^{\circ} \mathrm{C}$. The temperature of the furnace was ramped according to the program plotted in Fig. 14, which also indicates the typical oxygen versus time profile. A photo of the furnace and a close-up of one crucible containing the blended charge are shown in Fig. 13.

Alumina crucibles of $99.96 \%$ purity were used during these experiments. Previous work at NTNU [20] and TECNALIA had shown that high-purity alumina was the most suitable crucible material for potentially aggressive and unusual slags, as expected from these apatite experiments.

Experimental procedures were developed progressively through a total of 33 experiments. Six experiments were conducted using the final procedure: $10 \mathrm{~g}$ of apatite, $18 \mathrm{~g}$ of clay flux and $15 \mathrm{~g}$ of silicon, i.e., weight ratios of 1:1.8:1.5 at $1600{ }^{\circ} \mathrm{C}$, and using an argon atmosphere.

\section{Results and Discussion}

In order for silicon to react to extract phosphorus from the apatite at a reasonable rate, both the silicon and apatite should be present in the liquid state in order to maximize the interfacial areas. As the extraction reaction produces additional silica, it would be advantageous for the added silica to further depress the melting point, or at least not increase it. At the same time, a low viscosity would also be advantageous in order to promote rapid diffusion. As a result, the use of a very low basicity slags (e.g., $<0.5$ ) were considered to be counterproductive.

As seen in Fig. 11, it was initially expected that silica addition alone would be sufficient to produce a reasonably fluid, low-viscosity and low-melting slag with the apatite; however, the addition of 1.8 silica to 1.0 weight of apatite proved insufficient to result in a fully liquid slag at temperatures of up to $1550{ }^{\circ} \mathrm{C}$, see Fig. 15a through c.

The blue dot seen in Fig. 15a represents the initial concentration of the apatite concentrate. The dotted red line indicates the reduction path using silicon metal without fluxing, which follows a line of approximately constant $\mathrm{CaO}$ (56 wt\%). The liquidus quickly increases beyond $2000{ }^{\circ} \mathrm{C}$ with increasing degree of reduction, indicating that the silicothermic reduction would likely be very slow even at $1600{ }^{\circ} \mathrm{C}$, with the apatite/silica product being solid in the absence of fluxing.

From Fig. 15a, it is also clear that the initial addition of $\mathrm{SiO}_{2}$ flux to the apatite concentrate will result in a dramatic increase in liquidus requiring temperatures $>2000{ }^{\circ} \mathrm{C}$ to ensure rapid melting. Once sufficient silica is added to the initial apatite concentrate, the total slag will enter a multiphase region as indicated in Fig. 15a through c.

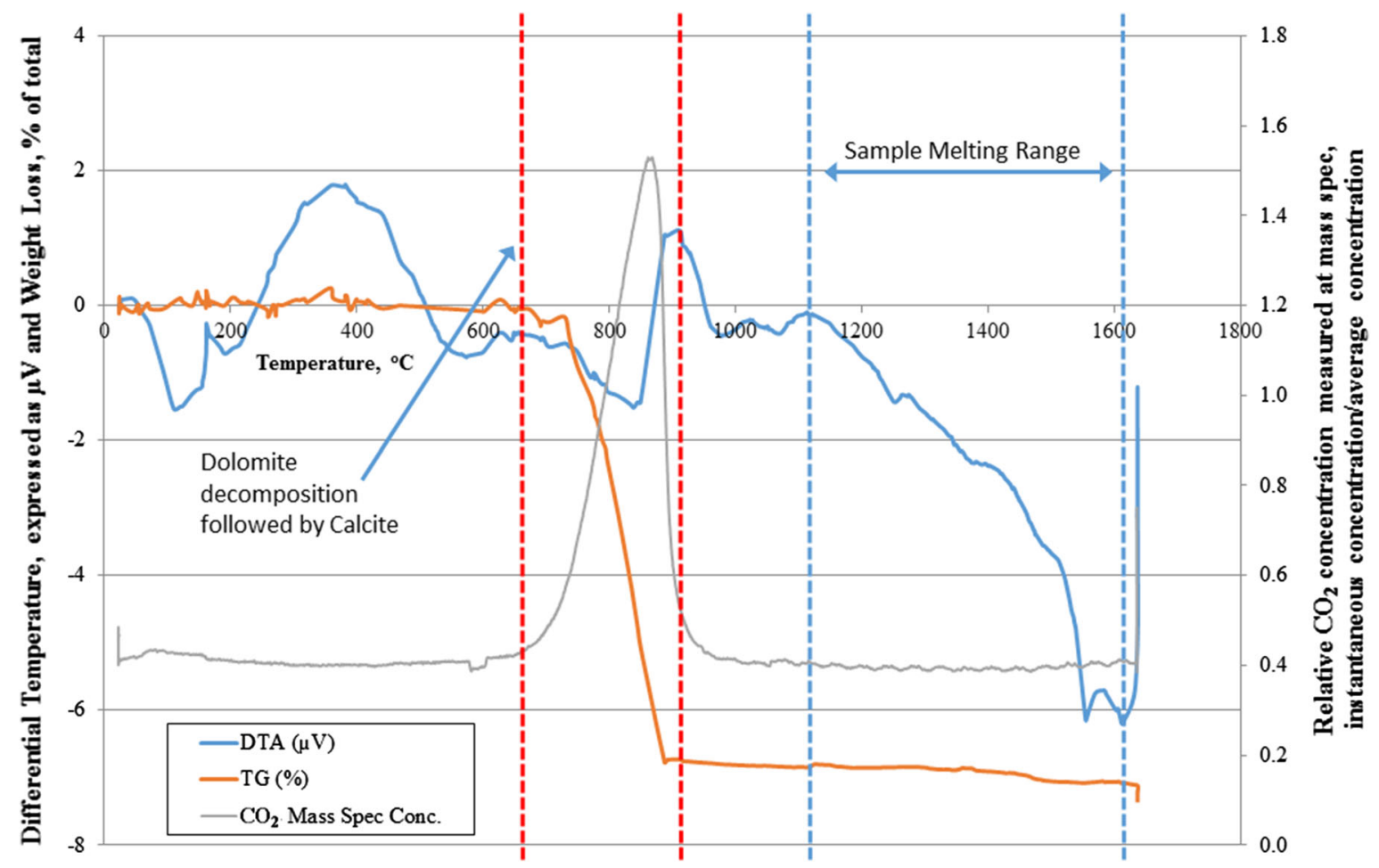

Fig. 8 DTA-TGA and mass spectrometer results of the apatite concentrate using a molybdenum crucible under argon atmosphere. The differential temperature curve (blue line), the weight-loss curve (tan line) and the relative $\mathrm{CO}_{2}$ concentration (gray line) versus temperature are presented (cooling period is not shown) (Color figure online) 


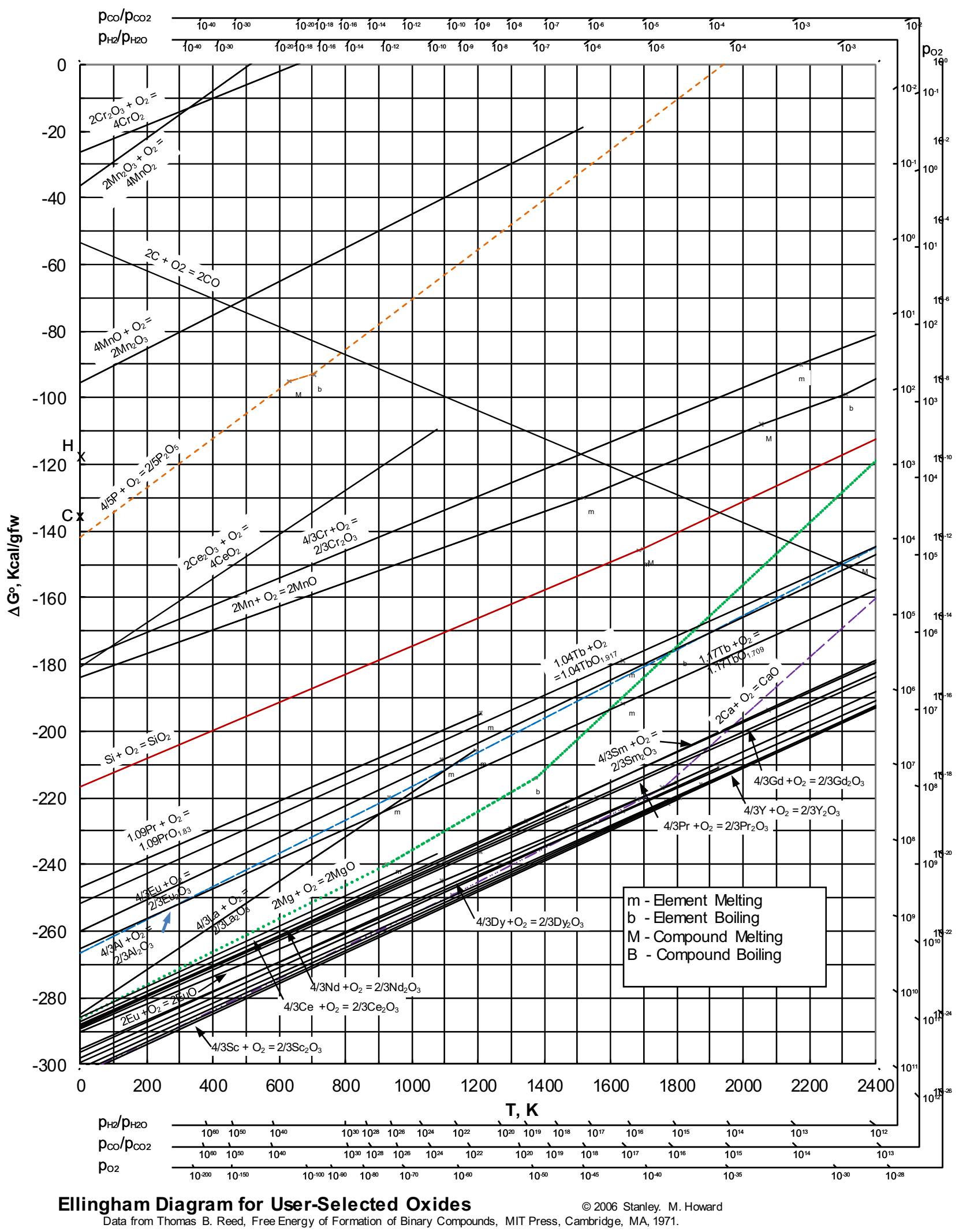

Fig. 9 Ellingham diagram indicating the REOs, the phosphorus, the most difficult to reduce transition elements and the possible metallothermic reductants. The diagram is based on the software by Howard [23] (Color figure online) 
Figure $15 \mathrm{~b}$ shows that at $1600{ }^{\circ} \mathrm{C}$ (the maximum possible temperature under argon for the current experimental apparatus), the slag would quickly saturate with solid $\mathrm{SiO}_{2}$. Even at $1800{ }^{\circ} \mathrm{C}$ the slag would enter a two-phase slag region, as shown in Fig. 15c), where one of the slags produced would be nearly pure $\mathrm{SiO}_{2}$ and therefore of extremely high viscosity. It is therefore concluded that

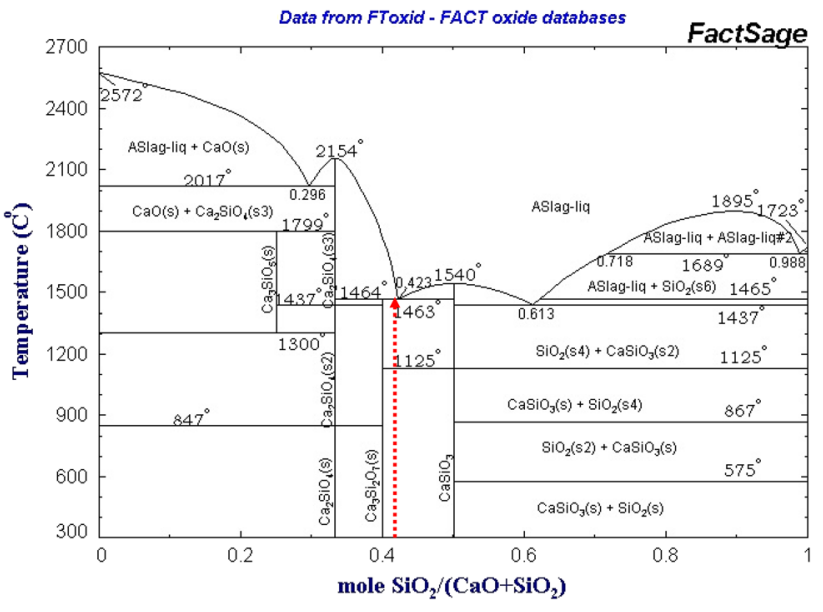

Fig. $10 \mathrm{CaO}-\mathrm{SiO}_{2}$ phase diagram using mole fractions [24] (Color figure online)

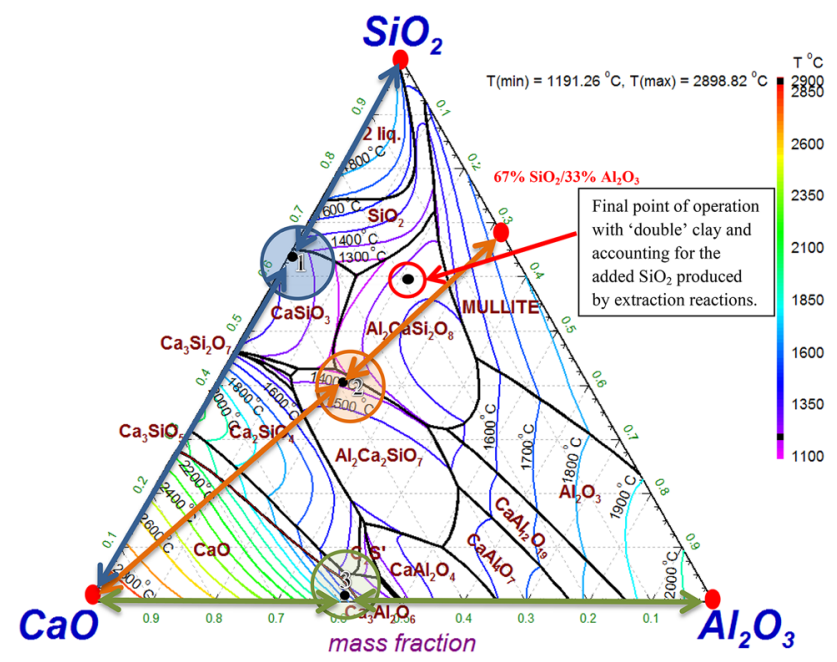

Fig. $11 \mathrm{CaO}-\mathrm{Al}_{2} \mathrm{O}_{3}-\mathrm{SiO}_{2}$ phase diagram indicating 3 possible low melting targets for silicothermic reduction of apatite concentrate achievable with the originally planned additions of (1) silica flux $\left(\sim 1465{ }^{\circ} \mathrm{C}\right)$, (2) clay flux $\left(\sim 1324{ }^{\circ} \mathrm{C}\right)$, and (3) alumina flux ( $\sim 1489{ }^{\circ} \mathrm{C}$ ), with phase diagram and liquidus values estimated using FactSage ${ }^{\circledR}$. The targets do not account for the amount of $\mathrm{SiO}_{2}$ produced during the reduction reactions (Color figure online) silica fluxing alone is not practically feasible with high phosphorus-containing apatite concentrates.

As previously mentioned, an alternative approach to fluxing with silica would be to use alumina flux. If the chemical reaction at the surface of a fluorapatite particle is considered, molten silicon metal will react to form $\mathrm{P}_{2}$ gas and a P-reduced calcium silicate (also containing small amounts of $\mathrm{CaF}_{2}$ ). As shown in Fig. 16, the blue point corresponds to a surface 'phosphate' content of $25 \% \mathrm{P}_{2} \mathrm{O}_{5}$, representing a $\mathrm{P}$ removal of $\sim 38 \%$.

The location of point on Fig. 16 indicates that the initial fluxing with alumina would require more than $2000{ }^{\circ} \mathrm{C}$ to achieve complete melting. Experiments held at $1450{ }^{\circ} \mathrm{C}$ for $60 \mathrm{~min}$, using an apatite concentrate to alumina ratio of 1:0.4, sintered. In other experiments, complete melting of the apatite was not achieved even with a final holding time of $140 \mathrm{~min}$ at $1550{ }^{\circ} \mathrm{C}$. It was subsequently decided to use clay flux as the main fluxing agent. Clay flux has the advantage that it is effectively 'self-fluxed' with a liquidus of $\sim 1782{ }^{\circ} \mathrm{C}$ relative to pure $\mathrm{Al}_{2} \mathrm{O}_{3}$ (m.p. $2054{ }^{\circ} \mathrm{C}$ ) making the melting/dissolution process easier and faster to achieve.

Using clay, it was quickly found that the optimal results (complete melting of the charge with an intact crucible until cooling) could be achieved using an apatite concentrate to clay ratio of $1: 1.8$, which was double the initially assumed target (the results for this final ratio are the focus of the present study). The final composition of the slag, expected to be produced at 1:1.8:1.5 apatite concentrate:clay:silicon ratio, was established to consist of $58.8 \% \mathrm{SiO}_{2}$, $18.9 \% \mathrm{CaO}$ and $22.3 \% \mathrm{Al}_{2} \mathrm{O}_{3}$. This would be achieved by fully removing the phosphorus, sodium, potassium as well as all transition metals from the slag, and excluding the calcium present as $\mathrm{CaF}_{2}$. This composition has been indicated on the phase diagram presented in Fig. 11. The initial (assuming full charge melting with no P-removal) and final slag composition, accounting for the maximum possible increase of $\mathrm{SiO}_{2}$ due to the reduction reactions, are shown in Table 6. Results are compared to the actual concentration after the experiments. The results from 3 experiments have been averaged.

The slag assay comparison in Table 6 indicates that the assumption of close to complete reduction seems reasonable. Initial and final masses for the 6 runs executed at $1600{ }^{\circ} \mathrm{C}$ are listed in Table 7 , and representative images are shown in Fig. 17. Note that runs 1 and 2 were held at full temperature for $60 \mathrm{~min}$, while the remainder of the runs were held for $90 \mathrm{~min}$. The average mass loss for the
Table 4 Composition of the clay flux used in the experimental program

\begin{tabular}{llllllllll}
\hline & $\mathrm{SiO}_{2}$ & $\mathrm{Al}_{2} \mathrm{O}_{3}$ & $\mathrm{CaO}$ & $\mathrm{MgO}$ & $\mathrm{Fe}_{2} \mathrm{O}_{3}$ & $\mathrm{TiO}_{2}$ & $\mathrm{~K}_{2} \mathrm{O}$ & $\mathrm{Na}_{2} \mathrm{O}$ & LOI @ $1000{ }^{\circ} \mathrm{C}$ \\
\hline Clay & 56.0 & 28.0 & 0.3 & 0.6 & 0.9 & 1.5 & 2.4 & 0.5 & 9.2 \\
\hline
\end{tabular}


Table 5 Some silicothermic reduction reactions of interest in the smelting of fluorapatite concentrate

\begin{tabular}{|c|c|c|c|}
\hline Reaction\# Number & Reaction & $\Delta \mathrm{G} \mathrm{kJ}$ at $1600^{\circ} \mathrm{C}$ & $\Delta \mathrm{H} \mathrm{kJ}$ at $1600{ }^{\circ} \mathrm{C}$ \\
\hline (1) & $\mathrm{Fe}_{2} \mathrm{O}_{3}+\mathrm{Si}=2 \mathrm{Fe}+1.5 \mathrm{SiO}_{2}$ & -587 & -517.6 \\
\hline (2) & $\mathrm{Ca}_{5}(\mathrm{PO} 4)_{3} \mathrm{~F}+3.75 \mathrm{Si}+3 \mathrm{Fe}=0.5 \mathrm{CaF}_{2}+4.5 \mathrm{CaO}+3 \mathrm{FeP}+3.75 \mathrm{SiO}_{2}$ & -241.5 & -415.3 \\
\hline (3) & $\left.\mathrm{Ca}_{5}\left(\mathrm{PO}_{4}\right)_{3} \mathrm{~F}+3.75 \mathrm{Si}=0.5 \mathrm{CaF}_{2}+4.5 \mathrm{CaO}+1.5 \mathrm{P}_{2(\mathrm{~g}}\right)+3.75 \mathrm{SiO}_{2}$ & -173.9 & 21.2 \\
\hline (4) & $\mathrm{CaF}_{2}+\mathrm{K}_{2} \mathrm{O}=\mathrm{CaO}+2 \mathrm{KF}$ & -170.4 & -223.3 \\
\hline$(5)$ & $\mathrm{CaO}+\mathrm{Al}_{2} \mathrm{O}_{3}+2 \mathrm{SiO}_{2}=\mathrm{CaO} \times \mathrm{Al}_{2} \mathrm{O}_{3} \times 2 \mathrm{SiO}_{2}$ & -148.5 & -0.3 \\
\hline$(6)$ & $\mathrm{CaF}_{2}+\mathrm{Na}_{2} \mathrm{O}=\mathrm{CaO}+2 \mathrm{NaF}$ & -124.1 & -203.4 \\
\hline (7) & $\mathrm{Ca}_{5}\left(\mathrm{PO}_{4}\right)_{3} \mathrm{~F}+6.75 \mathrm{Si}=0.5 \mathrm{CaF}_{2}+4.5 \mathrm{CaO}+3 \mathrm{SiP}+3.75 \mathrm{SiO}_{2}$ & -73.1 & -502.7 \\
\hline$(8)$ & $\mathrm{SiP}+\mathrm{Fe}=\mathrm{FeP}+\mathrm{Si}$ & -56.2 & 29.1 \\
\hline$(9)$ & $\mathrm{TiO}_{2}+0.5 \mathrm{Si}=\mathrm{TiO}+0.5 \mathrm{SiO}_{2}$ & -49.0 & -60.9 \\
\hline$(10)$ & $\mathrm{MnO}+0.5 \mathrm{Si}=\mathrm{Mn}+0.5 \mathrm{SiO} 2$ & -46.4 & -67.1 \\
\hline$(11)$ & $\left.\mathrm{Al}_{2} \mathrm{Si}_{2} \mathrm{O}_{7} \times 2 \mathrm{H}_{2} \mathrm{O}(\mathrm{D})=\mathrm{Al}_{2} \mathrm{O}_{3} \times 2 \mathrm{SiO}_{2}+2 \mathrm{H}_{2} \mathrm{O}_{(\mathrm{g}}\right)$ & $\begin{array}{l}\Delta \mathrm{G}=0 \text { at }{ }^{\circ} \mathrm{C} \\
579\end{array}$ & $\begin{array}{l}\Delta \mathrm{H} \mathrm{kJ} \text { at } \mathrm{T}_{\mathrm{e}} \\
271.8\end{array}$ \\
\hline (12) & $\left.\mathrm{Ca}_{5}\left(\mathrm{PO}_{4}\right)_{3} \mathrm{~F}+5.25 \mathrm{Si}=0.5 \mathrm{CaF}_{2}+4.5 \mathrm{CaO}+1.5 \mathrm{SiP}_{2(\mathrm{~g}}\right)+3.75 \mathrm{SiO}_{2}$ & 1200 & 390.3 \\
\hline (13) & $\left.\mathrm{K}_{2} \mathrm{O} \times \mathrm{SiO}_{2}+0.5 \mathrm{Si}=2 \mathrm{~K}_{(\mathrm{g}}\right)+1.5 \mathrm{SiO}_{2}$ & 1482 & 262.0 \\
\hline (14) & $\left.\mathrm{Na}_{2} \mathrm{SiO} 3+0.5 \mathrm{Si}=2 \mathrm{Na}_{(\mathrm{g}}\right)+1.5 \mathrm{SiO}_{2}$ & 1679 & 282.6 \\
\hline
\end{tabular}

Where: $T_{\mathrm{e}}$ is the temperature of equilibrium

Fig. 12 Expected distribution of phosphorus to gas and metal versus temperature at equilibrium, and distribution of phosphorus by species at $1600{ }^{\circ} \mathrm{C}$ (estimated using HSC Chemistry ${ }^{\circledR}$ version 7.1 [22] assuming ideal solutions and using the 1.8:1 clay:apatite concentrate fluxing ratio) (Color figure online)

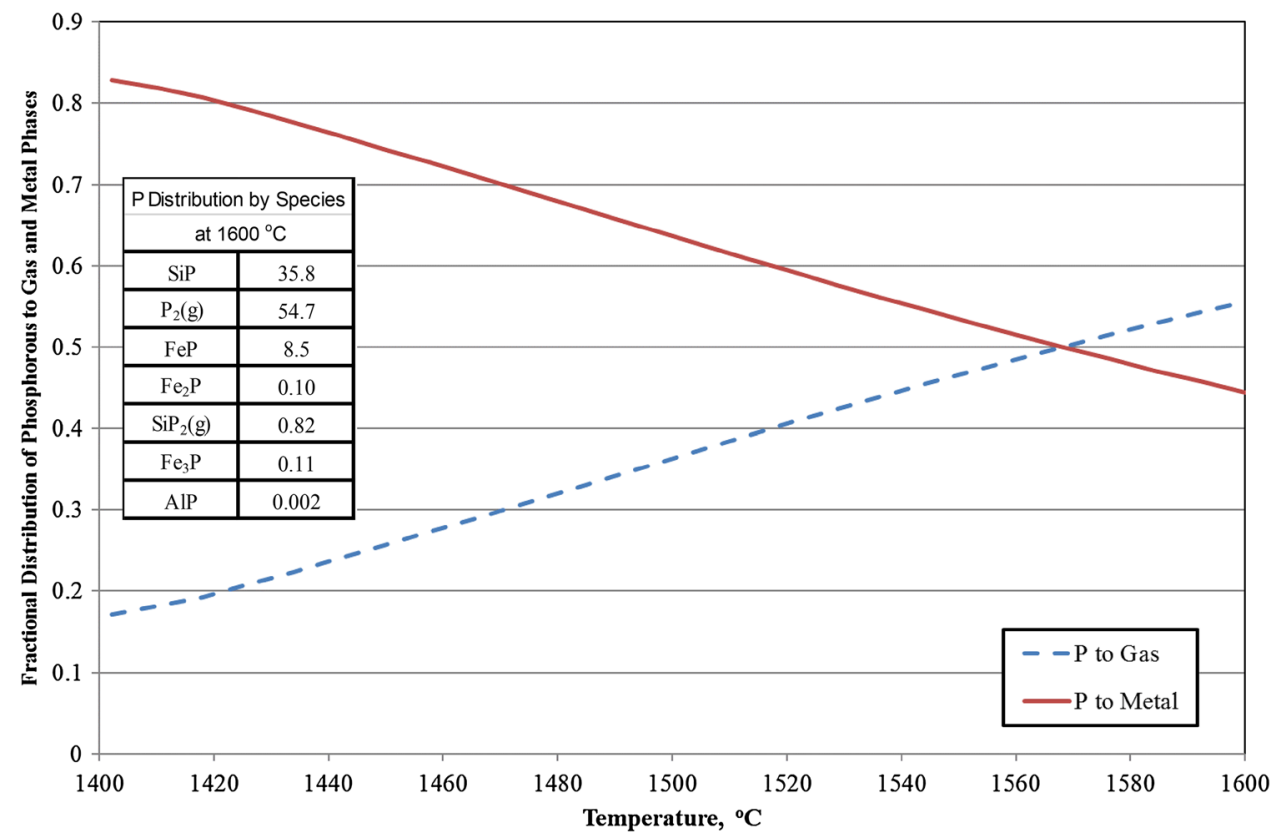

60 min runs was $6.7 \%$, while the average mass loss for the 90 min runs was $7.4 \%$, with an overall average of $7.2 \%$. Average metal and slag assays, percent mass distributions to metal and to slag, and mass distribution coefficients to slag, i.e., $\mathrm{L}^{\mathrm{S} / \mathrm{M}}=(\mathrm{wt} \%$ in slag $) /[\mathrm{wt} \%$ in metal] are given in Table 8.

Elemental accountability has been estimated using the initial masses and assays, accounting for silicothermic reduction of species above silicon in Fig. 9, as well as the loss to the gas phase of both LOI (crystal water from clay and $\mathrm{CO}_{2}$ from apatite) and a fraction of the $\mathrm{Na}, \mathrm{K}$ and $\mathrm{P}$ due to their volatility. A $\mathrm{CO}_{2}$ mass loss due to carbonates of $6.8 \%$ was assumed. Allowance was also made for a clay mass loss of $9.2 \%$ (equal to the L.O.I. measured at $1000{ }^{\circ} \mathrm{C}$ ). After 3 iterations using the "Heat and Material Balance" module of HSC Chemistry ${ }^{\circledR} 7.1$, the masses of the slag $(58.1 \%$ of total input), the metal $(33.1 \%)$, the gas $(7.4 \%)$ and the salt $(1.4 \%)$, as well as the relative mass distributions to each phase converged to the values shown in Fig. 18. The values also corresponds to the experimental 
Fig. 13 Furnace with the alumina crucibles used for the phosphorus extraction using silicon metal, as well as a closeup (Color figure online)
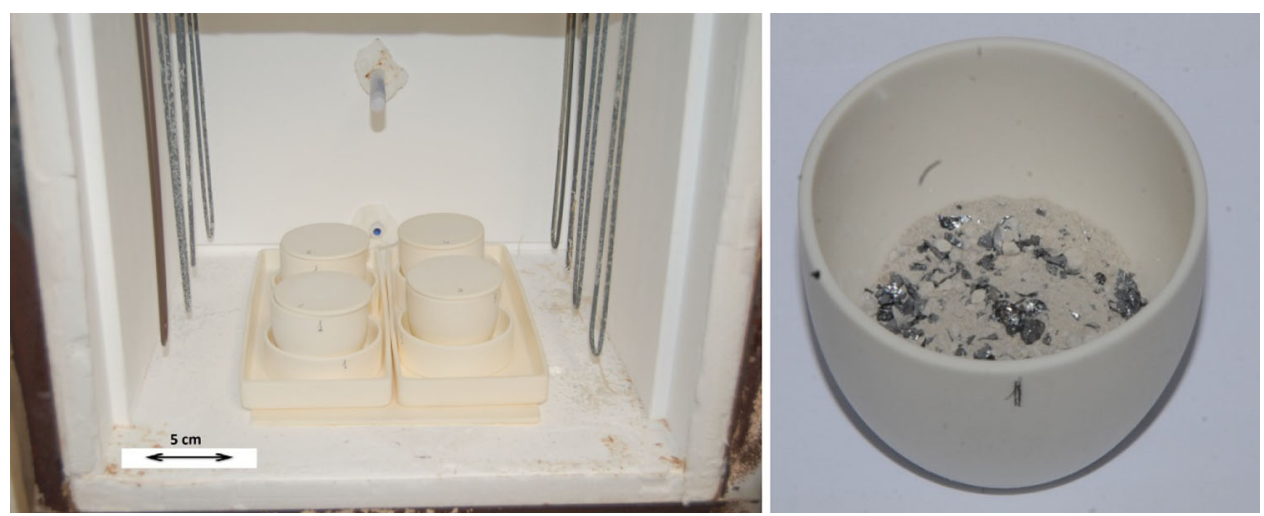

results in Table 8 . The estimated mass loss to gas was $7.4 \%$ using this method, versus the average measured mass loss of $7.2 \%$. The iterative procedure was required to estimate the mass deportment, as it was not possible to separately measure the masses of slag, metal, and salt at the completion of the experiments. This was mainly due to a partially dispersed metal phase, as well as the slag adherence to the crucible. Based on thermodynamic equilibrium calculations, the salt phase was assumed to be simply $\mathrm{CaF}_{2}$, as this should be the predominant fluoride at $1600{ }^{\circ} \mathrm{C}$.

As shown in Table 8, the distributions between the slag phase and the metal phase of typical slag species like K, $\mathrm{Na}, \mathrm{Al}, \mathrm{Mg}$, and $\mathrm{Ca}$ highly favored the slag phase, as indicated by the mass distribution coefficients (values vary from 127 for $\mathrm{Al}$ to 793 for $\mathrm{Ca}$ ). As shown in Fig. 9, one would expect that the distribution coefficients for the REEs would favor the slag to even a greater extent; however, this is not the case. The distribution coefficients for REEs were surprisingly low varying from only 2.2 for $\mathrm{Tb}$ to 30 for $\mathrm{Y}$ (the least and the most stable REEs depicted on Fig. 11). Evaluation of the apparent 'equilibrium' constant for $\mathrm{Nd}$ reduction by silicon, i.e., $\mathrm{Nd}_{2} \mathrm{O}_{3}+1.5 \mathrm{Si}=2 \mathrm{Nd}+1.5$ $\mathrm{SiO}_{2}$, would indicate a 5-6 order of magnitude difference between theoretical $\left(2 \times 10^{-12}\right.$ at $1600{ }^{\circ} \mathrm{C}$ and assuming ideal solutions) and observed value $\left(8 \times 10^{-7}\right.$ and assuming $\mathrm{SiO}_{2}$ and $\mathrm{Si}$ activities estimated using FactSage $\left.7.0^{\circledR}\right)$. This suggests that REEs are highly nonideal in either metal, slag or both, which is not surprising considering the ppm levels of the species involved. In other words, the assumption of ideal behavior was invalid.

As shown in Fig. 18, the distribution of species to the 'balance' represents the experimental and/or analytic error, as well as the losses to the gas phase. It is, however, impossible to separate the different parts of the 'balance' when using the applied calculation methodology. As expected, the phosphorus shows a high 'balance,' i.e.,

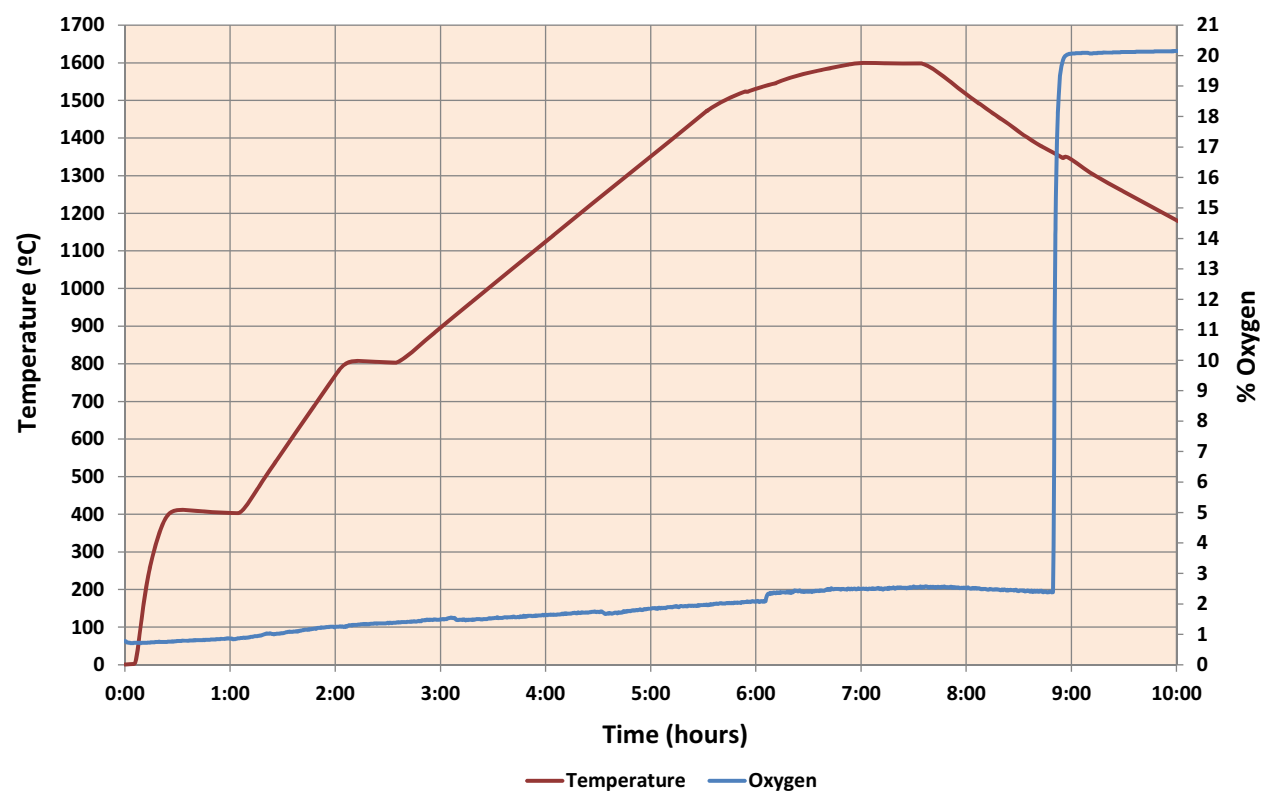

Fig. 14 Furnace temperature and oxygen profile versus treatment time for the silicothermic extraction experiments (Color figure online) 


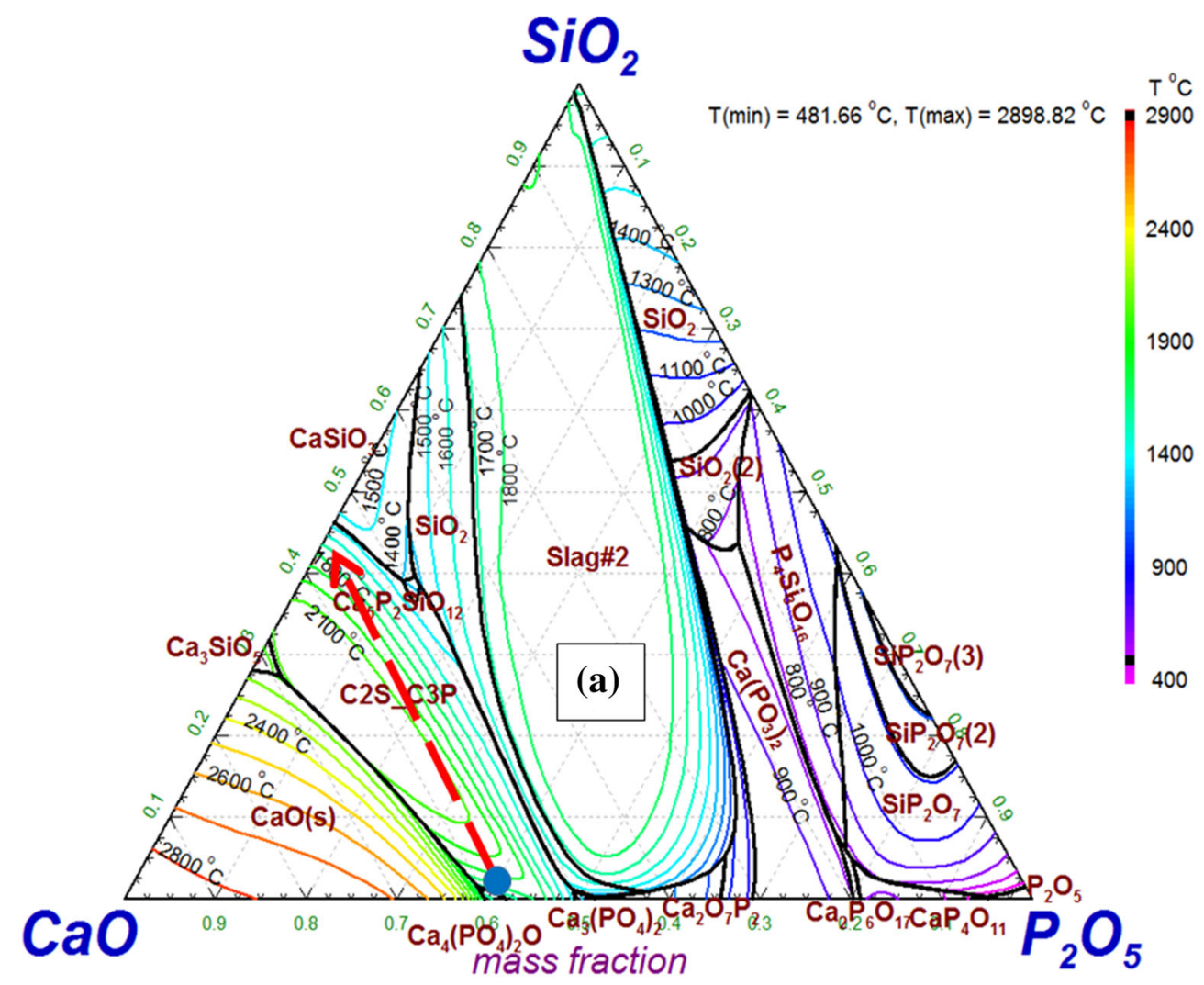

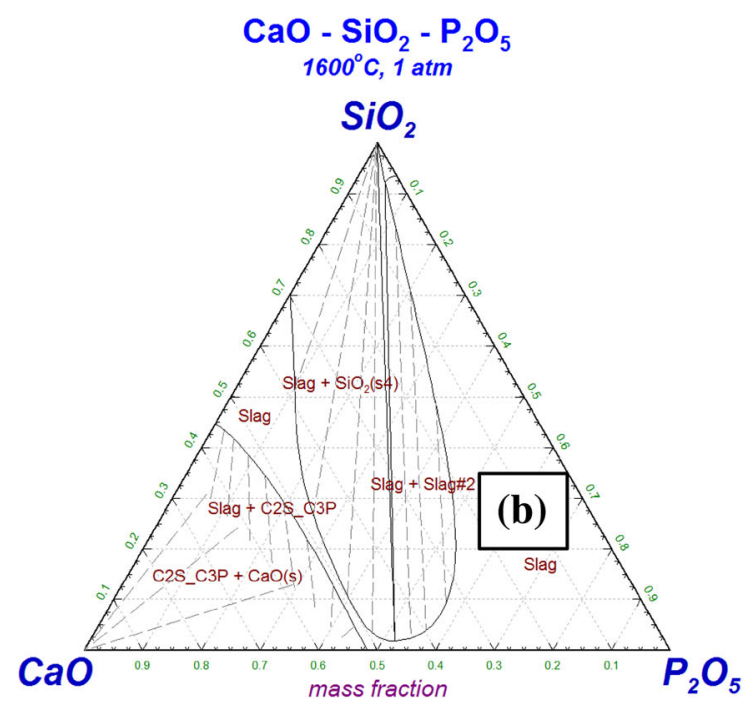

Fig. $15 \mathrm{CaO}-\mathrm{P}_{2} \mathrm{O}_{5}-\mathrm{SiO}_{2}$ phase diagrams showing a liquidus and twophase slag surface; blue-dot represents the initial apatite concentrate particle composition (excluding $\mathrm{Ca}$ present as $\mathrm{CaF}_{2}$ ), and the dotted-

distribution to gas. The distribution of phosphorus obtained from experiments matched well with the calculated results: for example, $46.7 \%$ obtained vs. $55.5 \%$ predicted and $51.3 \%$ obtained versus $44.5 \%$ predicted for gas and metal, respectively, as shown in Fig. 12. Less than $2 \%$ of the phosphorus remained in the slag phase. Also showing high

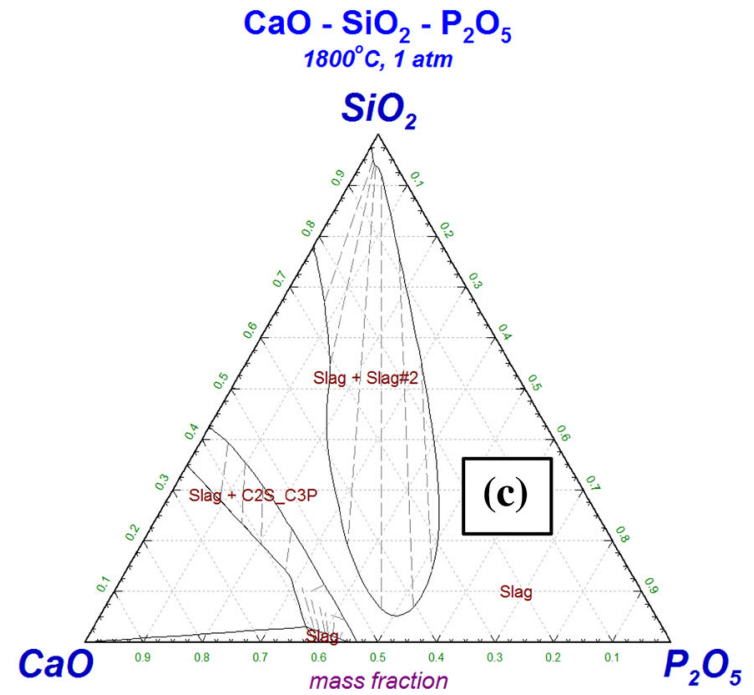

red line represents the reduction path using $\mathrm{Si}$ as a reductant in the absence of flux; $\mathbf{b}$ phase fields and tie-lines at $1600{ }^{\circ} \mathrm{C}$; and $\mathbf{c}$ phase fields and tie-lines at $1800{ }^{\circ} \mathrm{C}$ (Color figure online)

distributions to the gas phase were $\mathrm{K}(30.4 \%$ vs. $98 \%$ expected), $\mathrm{Mn}$ (21.6\% vs. $1.4 \%$ expected) and $\mathrm{Mg}(13.7 \%$ vs. $0.25 \%$ expected); however less $\mathrm{Na}$ than expected evaporated (9.5\% vs. $95 \%$ expected). $\mathrm{Al}$ is more than $100 \%$ accounted for, due to gain from the alumina crucible. The 'balances' for the REEs vary both positively and 
negatively, which most likely are due to random variation in the analytic results for these low concentration species. Given the simplifying assumption of ideal solutions, substantial variation between expected and actual distributions are not surprising, particularly for elements with low initial concentration.

It should be noted that the analytic results of the slag and metal used to generate Fig. 18 were only analyzed at a single laboratory, so the sample/sampling variance is not known in comparison with the initial apatite analytic results obtained via roundrobin testing, see Table 2.

SEM/EDS and XRD were performed on the metal and slag phases. Phosphorus was only detected by SEM/EDS in the metal phase and not in the slag phase. Different crystalline phases are formed in the metal, as shown in Fig. 19:

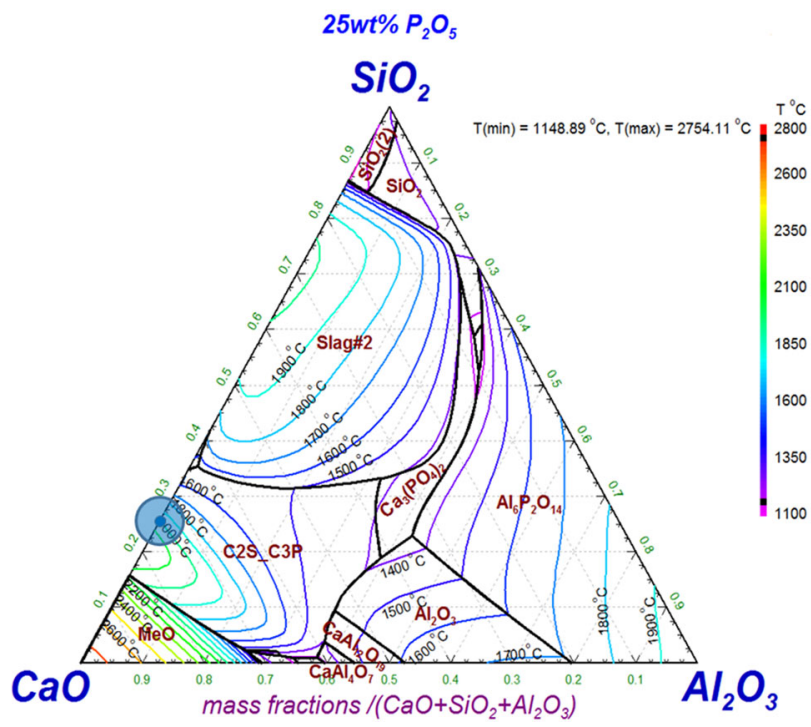

Fig. $16 \mathrm{CaO}-\mathrm{Al}_{2} \mathrm{O}_{3}-\mathrm{SiO}_{2}$ phase diagram with constant $25 \mathrm{wt} \% \mathrm{P}_{2} \mathrm{O}_{5}$. The blue dot indicates the composition at the surface of an apatite particle, which has been reacted with $\mathrm{Si}$ by $38 \%$ to achieve a local $\mathrm{P}$ concentration equivalent to $25 \mathrm{wt} \% \mathrm{P}_{2} \mathrm{O}_{5}$. The Ca present as $\mathrm{CaF}_{2}$ is excluded (Color figure online) (a) The major crystalline phase contains only Si 98.3 wt $\%$ and $\mathrm{P} 1.7 \mathrm{wt} \%$ (Spot 2).

(b) Other minority phases contain $\mathrm{P} 41.4 \mathrm{wt} \%$ and $\mathrm{Ti}$ $58.6 \mathrm{wt} \%$ (Spot 1), and

(c) Si $39.1 \mathrm{wt} \%$, Fe $17.6 \mathrm{wt} \%$ and $\mathrm{P} 43.3 \mathrm{wt} \%$ (Spot 3).

The metal-phase spectrum measured by XRD suggests $\mathrm{Si}, \mathrm{FeSi}_{2}$, and $\mathrm{SiP}$ as the main components, but not all the peaks of the spectrum were identified.

Phosphorus was not detected in the slag by SEM/EDS. Using EDS the slag was found to assay: Si $13.9 \mathrm{wt} \%, \mathrm{Ca}$ $4.5 \mathrm{wt} \%$, Al $7.5 \mathrm{wt} \%$ and $\mathrm{O} 74.1 \mathrm{wt} \%$, and the XRD analysis showed the presence of Anorthite/Dmisteinbergite $\left(\mathrm{CaAl}_{2} \mathrm{Si}_{2} \mathrm{O}_{8}\right)$ and Corundum $\left(\mathrm{Al}_{2} \mathrm{O}_{3}\right)$ as the main phases.

\section{Conclusions}

Phosphorus extraction is not feasible directly from the apatite concentrate at $1600{ }^{\circ} \mathrm{C}$ using only silicon as solvent; the addition of flux is required in order to avoid high melting and high viscosity compositions. A clay flux proved to give the best results.

REEs distribute more than $80 \%$ to the slag, while $\mathrm{P}$ is nearly completely removed from the slag, being fumed or dissolved into the silicon metal phase. The distribution of

Table 7 Initial and final masses for runs 1-6 processed under argon at $1600{ }^{\circ} \mathrm{C}$

\begin{tabular}{lclllll}
\hline RUN & 1 & 2 & 3 & 4 & 5 & 6 \\
\hline Apatite (g) & 10.00 & 10.00 & 10.00 & 10.00 & 10.00 & 10.00 \\
Clay (g) & 18.00 & 18.00 & 18.00 & 18.00 & 18.00 & 18.00 \\
Silicon (g) & 15.00 & 15.00 & 15.00 & 15.00 & 15.00 & 15.00 \\
Total initial mass (g) & 43.00 & 43.00 & 43.00 & 43.00 & 43.00 & 43.00 \\
Mass loss (g) & 2.91 & 2.79 & 3.25 & 3.13 & 2.97 & 3.42 \\
Total mass loss (\%) & 6.8 & 6.5 & 7.6 & 7.3 & 6.9 & 7.9 \\
\hline
\end{tabular}

Runs 1 and 2 were held for 60 instead of 90 min at $1600{ }^{\circ} \mathrm{C}$

Table 6 Estimated initial and final slag compositions compared with actual experimental observations (presented as the average of 3 observations)

\begin{tabular}{lccl}
\hline Compound & Apatite to clay ratio 1:1.8 & $\begin{array}{l}\text { All reducible species removed and accounting } \\
\text { for } \mathrm{SiO}_{2} \text { added via reduction reactions }\end{array}$ & $\begin{array}{l}\text { Actual observed average of 3 experiments } \\
\mathrm{CaO} \%\end{array}$ \\
\hline $\mathrm{Al}_{2} \mathrm{O}_{3} \%$ & 22.4 & 18.9 & 18.7 \\
$\mathrm{SiO}_{2} \%$ & 45.5 & 22.3 & 23 \\
$\mathrm{P}_{2} \mathrm{O}_{5} \%$ & 13.0 & 58.8 & 58.4 \\
Total & 100 & 0.0 & 0.25 \\
\hline
\end{tabular}



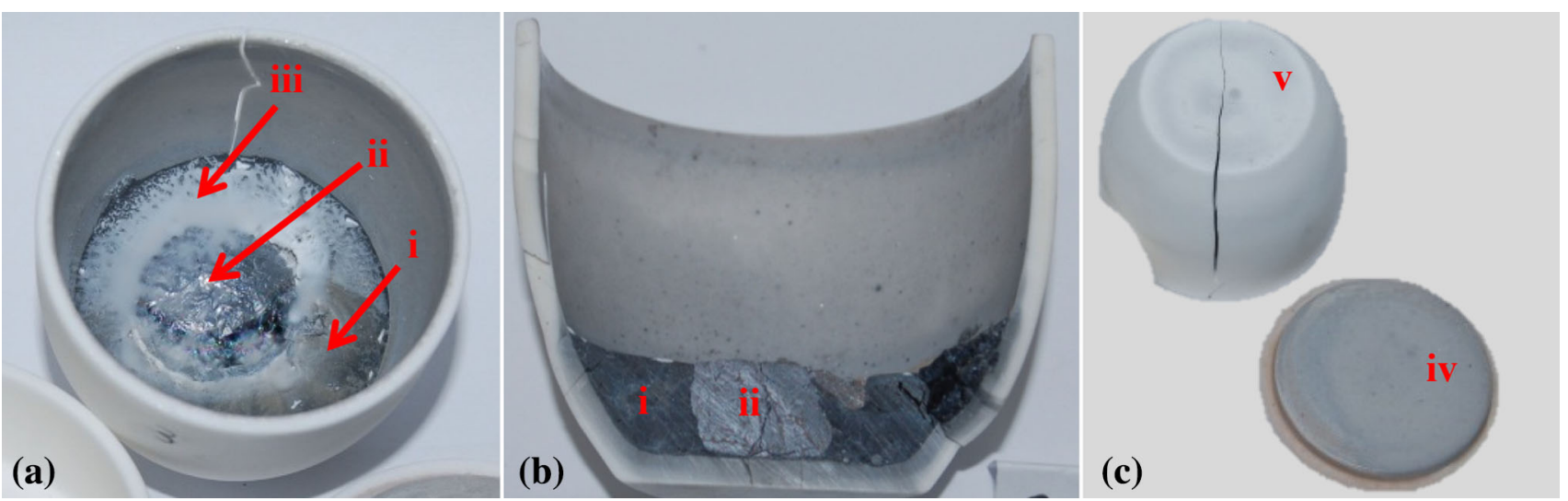

Fig. 17 Representative images of the experimental crucibles after use showing a a slag (i) with a silicon-based metal phase (ii), and a coating of white powder $\left(>96 \% \mathrm{SiO}_{2}\right)$ (iii); b detail of a section showing the slag (i) and the metal phase (ii); $\mathbf{c}$ a small amount of

condensate on the crucible lid after use (iv), and no damage to the crucible bottom which cracked first after cooling ( $v$ ) (Color figure online)

Table 8 Average metal and slag assays, mass distribution, and distribution coefficients for blends held under argon at $1600{ }^{\circ} \mathrm{C}$

\begin{tabular}{|c|c|c|c|c|c|c|c|c|}
\hline \multirow[t]{2}{*}{ Element } & \multirow[t]{2}{*}{ Units } & \multicolumn{7}{|c|}{ For experiments at $1600{ }^{\circ} \mathrm{C}$} \\
\hline & & $\begin{array}{l}\text { Metal } \\
\text { Average }\end{array}$ & $\begin{array}{l}\text { Coefficient of } \\
\text { variance }(\%)\end{array}$ & $\begin{array}{l}\text { Mass distribution } \\
\text { to metal (not } \\
\text { normalized) }\end{array}$ & $\begin{array}{l}\text { Slag } \\
\text { average }\end{array}$ & $\begin{array}{l}\text { Coefficient } \\
\text { of variance } \\
(\%)\end{array}$ & $\begin{array}{l}\text { Mass distribution } \\
\text { to slag (not } \\
\text { normalized) }\end{array}$ & $\begin{array}{l}\text { Distribution } \\
\text { coefficient to } \\
\text { slag }\end{array}$ \\
\hline $\mathrm{Ce}$ & $\mathrm{mg} / \mathrm{kg}$ & 161 & 29.1 & 12 & 759 & 7.9 & 102 & 4.7 \\
\hline Dy & $\mathrm{mg} / \mathrm{kg}$ & 9.5 & 7.4 & 16 & 24 & 29.5 & 72 & 2.5 \\
\hline $\mathrm{Gd}$ & $\mathrm{mg} / \mathrm{kg}$ & 7.7 & 26.6 & 8.4 & 40 & 14.3 & 76 & 5.2 \\
\hline $\mathrm{La}$ & $\mathrm{mg} / \mathrm{kg}$ & 45 & 53.9 & 7.6 & 274 & 6.6 & 82 & 6.1 \\
\hline $\mathrm{Nd}$ & $\mathrm{mg} / \mathrm{kg}$ & 76 & 29.9 & 13 & 228 & 7.4 & 71 & 3.0 \\
\hline $\operatorname{Pr}$ & $\mathrm{mg} / \mathrm{kg}$ & 22 & 35.4 & 17 & 62 & 7.1 & 83 & 2.8 \\
\hline $\mathrm{Sm}$ & $\mathrm{mg} / \mathrm{kg}$ & 6.0 & 53.9 & 6.3 & 43 & 8.3 & 80 & 7.2 \\
\hline $\mathrm{Tb}$ & $\mathrm{mg} / \mathrm{kg}$ & 3.0 & 35.1 & 27 & 6.7 & 9.4 & 103 & 2.2 \\
\hline $\mathrm{Y}$ & $\mathrm{mg} / \mathrm{kg}$ & 8.0 & 47.1 & 1.9 & 237 & 26.8 & 100 & 30 \\
\hline $\mathrm{Al}$ & $\%$ & 0.090 & 17.2 & 0.5 & 11 & 2.0 & 106 & 127 \\
\hline $\mathrm{Ca}$ & $\%$ & 0.015 & 34.7 & 0.1 & 12 & 11.6 & 82 & 793 \\
\hline $\mathrm{Fe}$ & $\%$ & 1.2 & 18.4 & 76 & 0.083 & 26.2 & 9.4 & 0.070 \\
\hline $\mathrm{K}$ & $\%$ & 0.0025 & 12.4 & 0.1 & 1.03 & 3.1 & 71 & 413 \\
\hline $\mathrm{Mg}$ & $\%$ & 0.0040 & 39.1 & 0.4 & 0.52 & 16.1 & 90 & 129 \\
\hline $\mathrm{Mn}$ & $\%$ & 0.090 & 10.0 & 85 & 0.0017 & 3.8 & 2.7 & 0.018 \\
\hline $\mathrm{Na}$ & $\%$ & 0.0045 & 5.5 & 0.7 & 0.33 & 25.6 & 87 & 74 \\
\hline $\mathrm{P}$ & $\%$ & 5.3 & 28.6 & 53 & 0.11 & 11.6 & 1.9 & 0.021 \\
\hline $\mathrm{Si}$ & $\%$ & 92 & 2.2 & 64 & 26 & 5.6 & 31 & 0.28 \\
\hline $\mathrm{Ti}$ & $\%$ & 0.52 & 6.2 & 45 & 0.21 & 12.6 & 32 & 0.41 \\
\hline
\end{tabular}

REEs were far from the expected equilibrium values, being approximately five orders of magnitude higher in the metal phase than what was expected based on the thermodynamic calculations assuming 'ideal solution' thermodynamic calculations (apparent equilibrium constants of $8 \times 10^{-7}$ versus the expected $2 \times 10^{-12}$ ).
The use of flux and $\mathrm{Si}$ in the REE extraction process results in a net decrease in the concentration of REEs in the final slag compared to the original apatite concentrate; however, the absence of phosphorus in the obtained slag opens a route for further processing by phase reformation. 
Fig. 18 Calculated average distribution of elements by phase for silicon-extraction experiments at $1600{ }^{\circ} \mathrm{C}($ Color figure online)

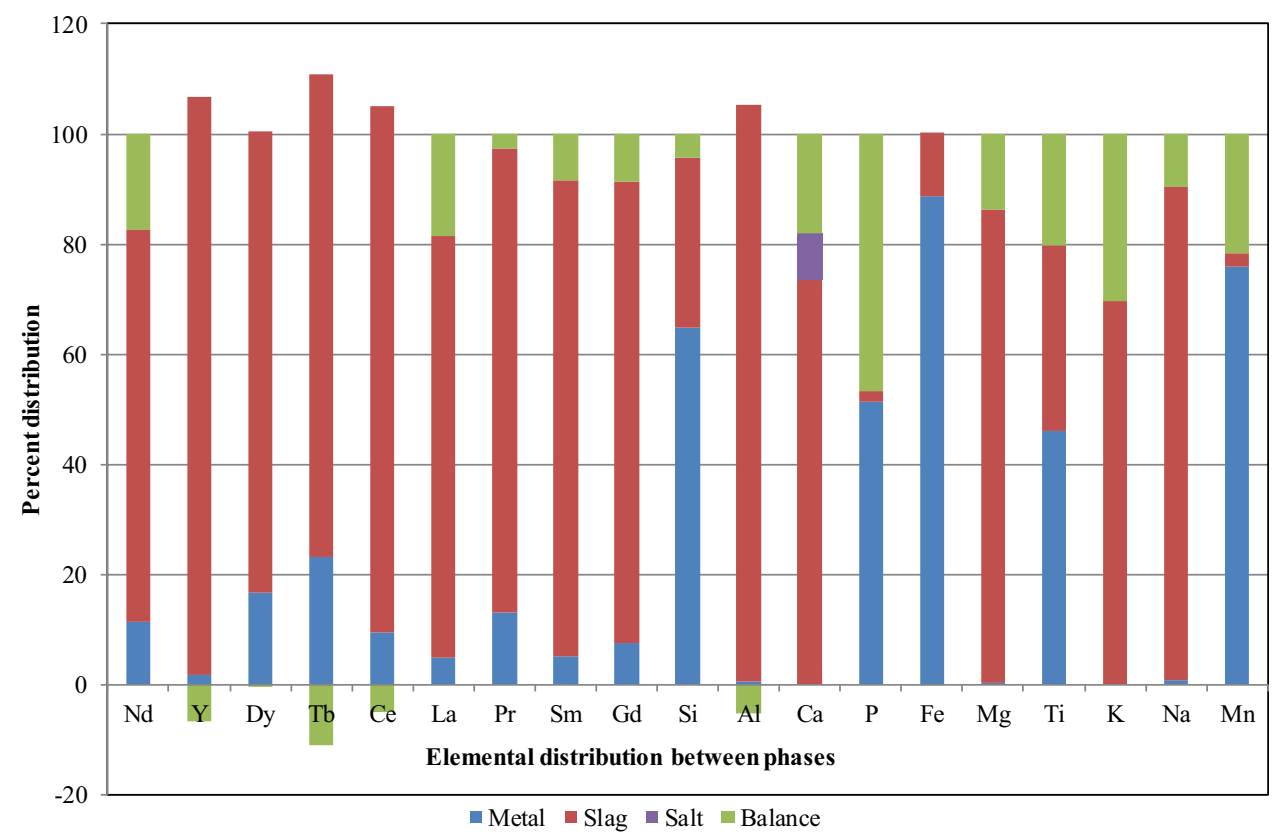

Acknowledgements The authors would like to thank their coparticipants in this EU-funded project (Grant FP7-603564-REEcover) for their assistance during the performance of the present work. Concerning apatite concentrate characterization in Chapter II, thanks are offered to: J.R. Tolchard for his help during the XRD analyses; Y. Yu and M.P. Raanes for their advice and work with SEM-EDS and EPMA; T. Anzjøn and S. Bao for their help with the wetting and DTA-TGA-MS analyses; and T. Schanche and D. Leroy for their experimental assistance. The primary author also would like to offer his thanks to the Chinese Scholarship Council (CSC) for funding his $\mathrm{Ph}$.D. research.

Open Access This article is distributed under the terms of the Creative Commons Attribution 4.0 International License (http://crea tivecommons.org/licenses/by/4.0/), which permits unrestricted use, distribution, and reproduction in any medium, provided you give appropriate credit to the original author(s) and the source, provide a link to the Creative Commons license, and indicate if changes were made.

\section{References}

1. E.U. Commission (2014) Report on Critical Raw materials for the EU:1-41

2. E.U. Commission (2015) A Report by the European Rare Earths Competency Network (ERECON) Strengthening the European Rare Earths Supply-Chain Challenges and policy options:1-104

3. Goonan TG (2011) Rare earth elements-end use and recyclability: US Department of the Interior. US Geological Survey:1-22

4. Castor SB, Hedrick JB (2006) Rare earth elements. Industrial minerals volume, 7th edn. Society for Mining, Metallurgy, and Exploration, Littleton, pp 769-792

5. Rare earths statistics. http://minerals.usgs.gov/minerals/pubs/his torical-statistics/ds140-raree.xlsx. Accessed 27 Feb 2016

6. European Rare Earths Competency Network (ERECON). https:// ec.europa.eu/growth/sectors/raw-materials/specific-interest/ere con_en. Accessed 28 Nov 2016 
7. HydroWEEE report summary. http://cordis.europa.eu/result/ren/ 45388_en.html. Accessed 28 Nov 2016

8. EURARE homepage. http://www.eurare.eu/. Accessed 28 Nov 2016

9. RE-CLAIM Homepage. http://www.re-claim.eu/. Accessed 28 Nov 2016

10. REEcover homepage. http://www.reecover.eu/. Accessed 28 Nov 2016

11. Pålsson BI, Fredriksson A (2012) Apatite for extraction. II. Flotation of apatite and rare earth elements from old tailings dumps. In: XXVI International Mineral Processing Congress (IMPC), New Dehli, India, pp 04064-04075

12. Kennedy MW, Sun T, Yurramendi L, Arnout S, Aune RE and Tranell G (2017) Pyrometallurgical treatment of apatite concentrate with the objective of rare earth element extraction. Part II. J Sustain Metal. https://doi.org/10.1007/s40831-017-0148-y

13. Sarasola LY (2015) REEcover WP3-Task 3.4-silicon as solvent and separator tests for pyrometallurgical upgrade of apatite tailing. Tecnalia report:1-139

14. Palsson BI, Martinsson O, Wanhainen C, Fredriksson A (2014) Unlocking rare earth elements from european apatite-iron ores. In: 1st European rare earth resources conference (ERES), pp 211-220

15. (2016) D6.2 Round Robin test of selected analytical technique and/or material (final update). Tecnalia Report:1-64

16. Peelman S, Sun ZHI, Sietsma J et al (2016) Hydrometallurgical extraction of rare earth elements from low grade mine tailings. In:
Alam S, Kim H, Neelameggham NR, Ouchi T, Oosterhof H (eds) Rare metal technology 2016. TMS, Warrendale

17. Pålsson BI, Martinsson O, Wanhainen C, Frederiksson A (2014) Unlocking rare earth elements from European apatite-iron ores. In: Proceedings 1st European Rare Earth Resources Conference (ERES2014), pp 211-220

18. Wanhainen C, Pålsson BI, and Eriksson AE (2016) New REE Mineralogy for LKAB Apatite-Iron Ores. Presented at Mineral Teknik 2016

19. ICP-MS method - trace element analyses of rocks and minerals by ICP-MS. http://cahnrs.wsu.edu/soe/facilities/geolab/technotes/ icp-ms_method/. Accessed 28 Nov 2016

20. Sun T, Kennedy MW, Tranell G et al (2015) Apatite concentrate, a potential new source of rare earth elements. In: Neelameggham NR, Alam S, Oosterhof H, Jha A, Dreisinger D, Wang S (eds) Rare metal technology 2015. TMS, Warrendale

21. Pandya JR, Mehta BJ (1969) The melting point of synthetic apatites. Miner Mag 37:527-528

22. https://www.outotec.com/products/digital-solutions/hsc-chem istry/hsc-sim-process-simulation-module/. Accessed 15 Sept 2016

23. Howard SM. EllinghamMaker_v12-5.xls. http://showard.sdsmt. edu/MET320/Handouts/EllinghamDiagrams/EllinghamMaker_ v12-5.xls. Accessed 24 Mar 2016

24. FactSage Database Documentation. http://www.crct.polymtl.ca/ fact/documentation/. Accessed 28 Nov 2016

25. Arnout S, Nagels E (2016) Modelling thermal phosphorus recovery from sewage sludge ash. Calphad 55(1):26-31 